Archive for

Organic Chemistry

Arkivoc 2020, part v, 39-58

\title{
Synthesis and in vitro Leishmania promastigote growth inhibition efficacy of novel 4(3H)-quinazolinone derivatives
}

\author{
Greg L. Ralph, ${ }^{a}$ Nonkululeko H. Zuma, ${ }^{a}$ Janine Aucamp,, ${ }^{b}$ and David D. N'Da*a \\ a Pharmaceutical Chemistry, School of Pharmacy, North-West University, Private Bag X6001, \\ Potchefstroom, 2520, South Africa \\ ${ }^{b}$ Centre of Excellence for Pharmaceutical Sciences, North-West University, Potchefstroom 2520, South Africa \\ Email: david.nda@nwu.ac.za
}

Received 07-24-2020

Accepted 09-15-2020

Published on line 09-19-2020

\section{Abstract}

Molecular hybridization is an increasingly important strategy in rational drug design and development. A series of novel quinazolinone-triazole hybrids have been synthesized and their antileishmanial activity investigated. Derivatives (E)-3-(prop-2-yn-1-yl)-2-styrylquinazolin-4(3H)-one, and (E)-3-\{[1-(4-bromobenzyl)-1H-1,2,3-triazol4-yl]methyl\}-2-styrylquinazolin-4(3H)-one were observed to moderately inhibit the growth of promastigotes. An overall lack of significant antileishmanial activity may be attributable to the poor aqueous solubility of the derivatives. Future research endeavors will focus on potential remediation by investigating the anchoring of hydrophilic moieties to the quinazolinone scaffold.

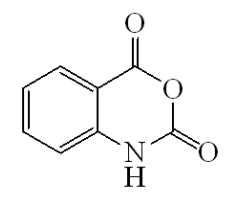

Isatoic anhydride

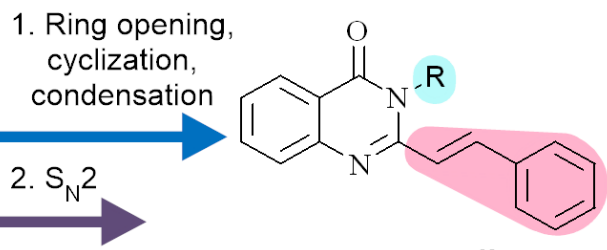

3. CUAAC
$4 \mathrm{~b}$

R: 2a

R:

Activity (\% growth inhib.) - $100 \mu \mathrm{M}$ :

2a:

L. don 1S: 58

L. don 9515: 44

Vero IC I0 $_{50}>100 \mu \mathrm{M}$

cLogP: 3.4 4b:

L. maj IR-173: 48

Vero $I_{50}>100 \mu \mathrm{M}$ cLogP: 4.6

Keywords: Leishmaniasis, promastigote, molecular hybridization, quinazolinones, 1,2,3-triazoles 


\section{Introduction}

Leishmaniasis is a parasitic disease characterized by infection with an obligate intracellular parasite of the genus Leishmania. ${ }^{1}$ The disease is primarily transmitted by the bite of an infected female phlebotomine sandfly. ${ }^{2}$ Leishmaniasis is one of several infectious diseases of the tropics and sub-tropics that constitute a steadily increasing public health burden. This is the result of a variety of factors, including, inter alia, the coinfection with human immunodeficiency virus $(\mathrm{HIV})^{3}$, and the migration of immigrants and refugees from areas of known endemicity. ${ }^{4}$ Leishmaniasis is classified as a neglected tropical disease (NTD) due its low visibility amongst the public of high-income countries, and a paucity of research investment on the part of the pharmaceutical sector and policy makers. ${ }^{5}$

Leishmaniasis is endemic to ninety-eight countries and territories, where an estimated one billion people are at risk of contracting this disease. ${ }^{6}$ There are over twenty Leishmania species, ${ }^{7}$ of which only three are predominantly responsible for the three clinical forms of the disease in humans. ${ }^{8}$ These include: (i) $L$. major, which causes the most common form of the disease, i.e., cutaneous leishmaniasis $(\mathrm{CL})$, which is seen to cause the development of ulcers and skin lesions across exposed areas of the body; ${ }^{6}$ (ii) L. donovani, responsible for visceral leishmaniasis (VL), the most lethal form of the disease with a $95 \%$ fatality rate if left untreated, and which is typified by symptoms such as fever, weight loss, fatigue, and an enlarged spleen and liver ${ }^{6,8}$; and (iii) L. braziliensis, which causes mucocutaneous leishmaniasis $(\mathrm{MCL})$, and is characterized by a partial or complete loss of the mucous membranes in the mouth, nose and throat. ${ }^{6,8}$ In 2019 alone, around 600,000 - 1 million new cases of cutaneous leishmaniasis, and some 50,000-90,000 new cases of the visceral form of the disease, were reported to have occurred worldwide. ${ }^{6}$

The treatment of human leishmaniasis is limited to the chemotherapeutic use of only a handful of drugs, which include the pentavalent $\left(\mathrm{Sb}^{\mathrm{V}}\right)$ antimonials (sodium stibogluconate and meglumine antimoniate), amphotericin B, miltefosine, pentamidine, and paromomycin (Figure 1). The use of these drugs, however, is negatively associated with treatment failure, the emergence of drug-resistant pathogenic strains in both experimental and clinical settings, as well as the occurrence of toxicity and adverse events. ${ }^{9}$ Altogether, these shortcomings serve to stress the need for new and effective leishmanicidal agents.

The development of novel chemical entities with entirely new mechanism(s) of action is expensive, time consuming and fraught with risk. ${ }^{10}$ It is, therefore, desirable, instead, to make use of drug development strategies that exploit structures with known biological activities. One such a strategy is molecular hybridization, a strategy in rational drug design and development wherein two or more pharmacophoric subunits, derived from structures with known biological activity, are joined into one single structure. ${ }^{11}$ The resulting hybrid is expected to have greater potency, efficacy and affinity compared to the respective parent molecules. The strategy has been utilized with great success to generate promising chemotherapeutic agents to prevent or treat tropical parasitic diseases, such as malaria, ${ }^{12}$ trypanosomiasis and leishmaniasis. ${ }^{13}$

Quinazolinones are a class of heterocycles comprised of fused nitrogen-containing rings that occur naturally in the form of some 200 alkaloids in plants, ${ }^{14}$ as well as metabolites derived from microorganisms, such as Bacillus cereus. ${ }^{15}$ Synthetic, as well as semi-synthetic, quinazolinones are also extant in the scientific literature. ${ }^{16}$ This class of compounds has attracted considerable attention in medicinal chemistry owing to the ease of its synthesis, and the fact that it elicits a range of biological activities, including, inter alia, antimalarial, ${ }^{17}$ antimycobacterial ${ }^{18}$ and antileishmanial ${ }^{19}$ activity.

1,2,3-Triazoles hold a significant importance in drug discovery for their ability to evoke a myriad of biological activities, chief among these being their antiprotozoal activities against the pathogens of diseases such as malaria, ${ }^{20}$ leishmaniasis $^{21}$ and trypanosomiasis. $^{22}$ They are readily synthesized by Huisgen 
cycloaddition ${ }^{23}$ or copper-catalyzed alkyne-azide cycloaddition (CuAAC) reactions ${ }^{24}$ between terminal alkynes and azides.<smiles>CNC[C@H](O)[C@H](O)[C@H](O)[C@H](O)CO</smiles>

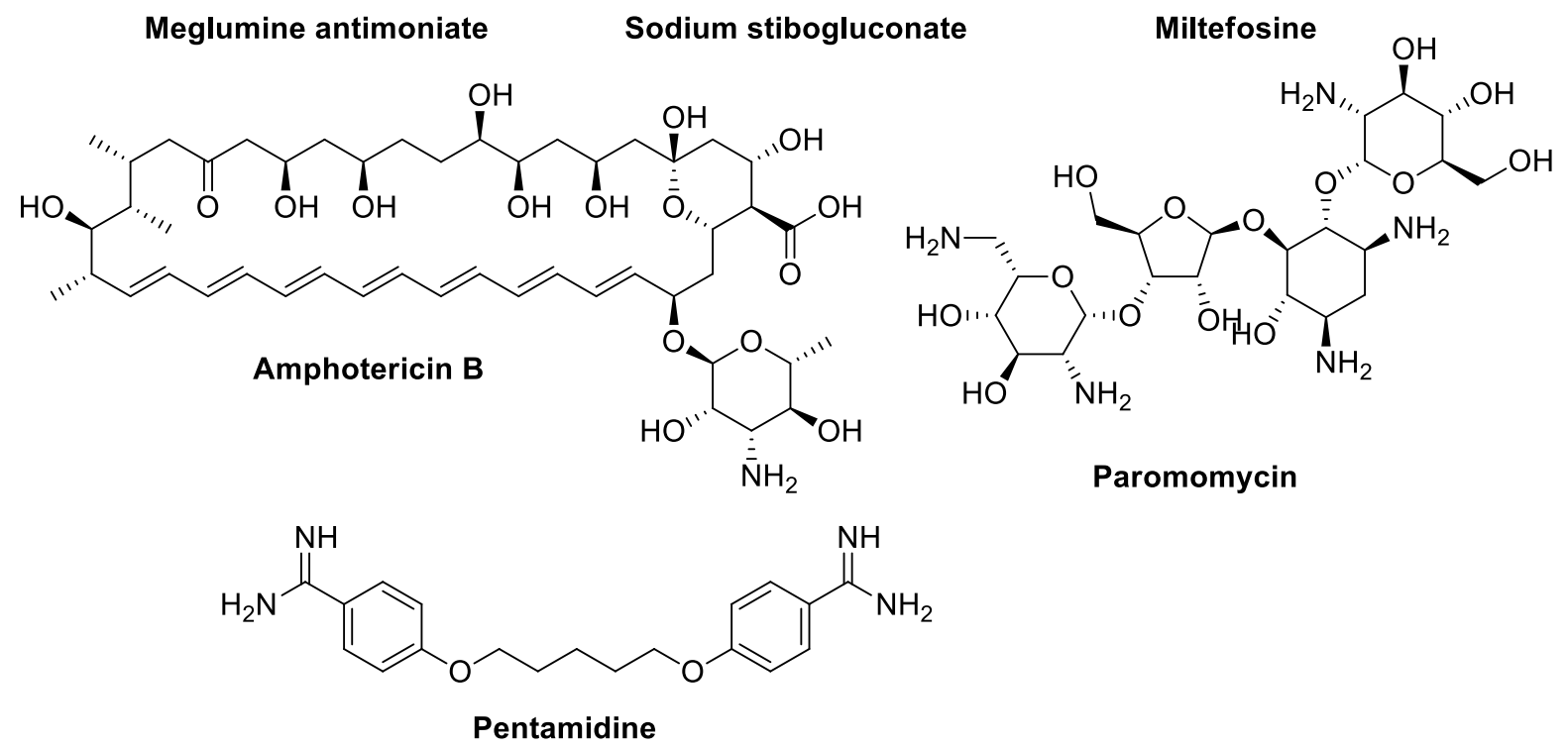

Figure 1. Clinical antileishmanial drugs.

In this study, a series of novel quinazolinone-triazole hybrids were synthesized, using a variety of synthetic routes, and their cytotoxicity profiles, as well as their ability to inhibit the growth of Leishmania promastigotes, were assessed in vitro. We, herein, report the syntheses and biological properties of these hybrids.

\section{Results and Discussion}

\section{Chemistry}

A series of fourteen quinazolinone derivatives were synthesized using a variety of synthetic methods. The compounds were divided into three distinct sub-series, namely 2-(4-substituted-styryl)-4(3H)-quinazolinones (1a,b), 3-propyl-2-(4-substituted-styryl)-4(3H)-quinazolinones $\quad(2 \mathbf{2}, \mathbf{b}), \quad$ and $1 H$-1,2,3-triazole-4(3H)quinazolinones (4a-j), as shown in Table 1. The entirety of the synthetic process is illustrated in Scheme 1.

First, the 2-(4-substituted-styryl)-4(3H)-quinazolinones $(\mathbf{1} \mathbf{a}, \mathbf{b})$ were synthesized in a two-step, tandem onepot process using an established method. ${ }^{25}$ Commercially-available isatoic anhydride was subjected to ringopening by ammonium acetate $\left(\mathrm{NH}_{4} \mathrm{Ac}\right)$ to produce anthranilamide, following the loss of carbon dioxide. The in-situ cyclization with triethyl orthoacetate $\left(\mathrm{CH}_{3} \mathrm{C}(\mathrm{OEt})_{3}\right)$ at $120^{\circ} \mathrm{C}$ for $6-8 \mathrm{~h}$ generated the $2-\mathrm{methyl}-4(3 \mathrm{H})$ quinazolinone intermediate. Condensation of this intermediate with a substituted benzaldehyde, again at 120 ${ }^{\circ} \mathrm{C}$ for $6-8 \mathrm{~h}$, yielded $1 \mathbf{a}(60 \%)$ and $\mathbf{b}(50 \%)$ after purification by precipitation in $\mathrm{H}_{2} \mathrm{O}$. 
<smiles>O=c1[nH]c2ccccc2c(=O)o1</smiles>

Isatoic anhydride<smiles>[R]c1ccc(C[AlH2])cc1</smiles>

Benzyl bromide

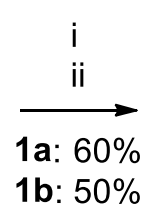

1b: $50 \%$
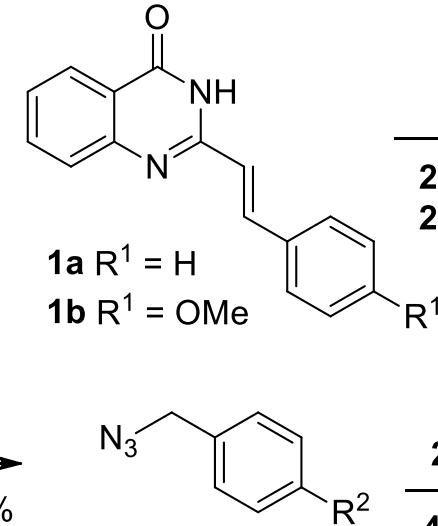

3a: $100 \%$

3b: $100 \%$

3c: $70 \%$

3d: $70 \%$

3e: $95 \%$
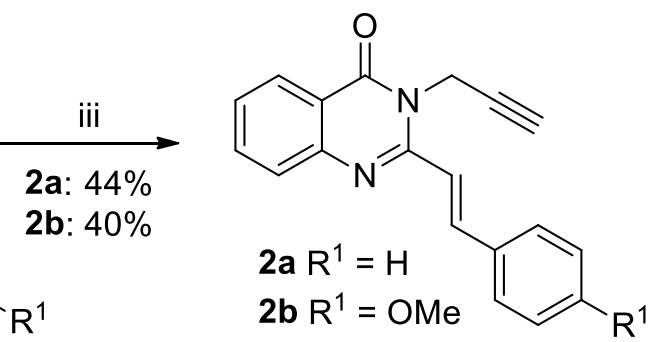

$2 a, b, v$

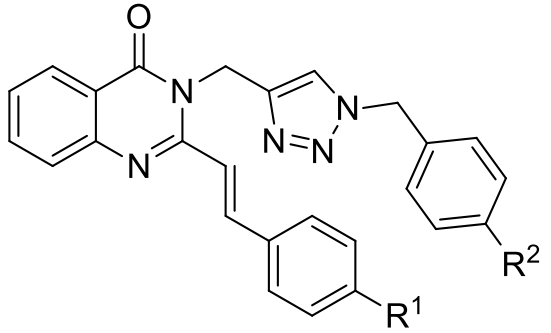

$$
\begin{array}{rlrl}
\text { 4a } R^{1}=H ; R^{2}=N_{2} & & \text { 4f } R^{1}=O M e ; R^{2}=N_{2} \\
\text { 4b } R^{1}=H ; R^{2}=B r & & \text { 4g } R^{1}=O M e ; R^{2}=B r \\
\text { 4c } R^{1}=H ; R^{2}=F & & \text { 4h } R^{1}=O M e ; R^{2}=F \\
\text { 4d } R^{1}=H ; R^{2}=H & \text { 4i } R^{1}=O M e ; R^{2}=H \\
\text { 4e } R^{1}=H ; R^{2}=M e & \text { 4j } R^{1}=O M e ; R^{2}=M e
\end{array}
$$

Scheme 1. Multi-step synthesis of quinazolinone-triazole hybrids. Reagents and conditions: i) $\mathrm{NH}_{4} \mathrm{OAc}(3.78 \mathrm{~g}$, 1 eq.), $\mathrm{CH}_{3} \mathrm{C}(\mathrm{OEt})_{3}\left(1\right.$ eq.), $120{ }^{\circ} \mathrm{C}, 6-8 \mathrm{~h}$ then ii) benzaldehyde/p-methoxy benzaldehyde (1 eq.), $120{ }^{\circ} \mathrm{C}, 6-8 \mathrm{~h}$ (ref. 25); iii) 1a,b (1eq.), $\mathrm{K}_{2} \mathrm{CO}_{3}$ (12 eq.), DMF, PB (1.2 eq.), r.t, 15 min - 48 h (ref. 26); iv) $\mathrm{NaN}_{3}$ (1.1 eq.), DMSO, r.t, 10-12 h (ref. 27); v) 2a,b (1eq.), DMSO- $\mathrm{H}_{2} \mathrm{O}$ (4:1), $\beta-\mathrm{CD}$ (0.07 eq.), Na L-ascorbate (0.3 eq.), $\mathrm{CuSO}_{4} \cdot 5 \mathrm{H}_{2} \mathrm{O}(0.1$ eq.), r.t, 48-72 h (ref. 27).

Second, the 3-propyl-2-(4-substituted styryl)-4(3H)-quinazolinones $(\mathbf{2 a}, \mathbf{b})$ were prepared by employing a literature method. ${ }^{26}$ This involved $\mathrm{N}$-alkylation of the quinazolinone through a nucleophilic substitution $\left(\mathrm{S}_{\mathrm{N}} 2\right)$ reaction between $\mathbf{1} \mathbf{a}, \mathbf{b}$ and propargyl bromide at the $\mathrm{N}-3$ position of the quinazolinone moiety. The procedure was carried out at room temperature for a duration of $15 \mathrm{~min}(\mathbf{2 b})$ to $48 \mathrm{~h}(\mathbf{2 a})$ in the presence of potassium carbonate, to produce the target compounds in moderate yields, $\mathbf{2 a}(44 \%)$ and $\mathbf{2 b}(\mathbf{b} \mathbf{6})$, after purification by recrystallization in EtOH or acetone.

Third, the quinazolinone-triazole hybrids (4a-j) were produced using methods outlined in the literature. ${ }^{27}$ Benzyl azides (3a-e) were synthesized through nucleophilic substitution reactions $\left(S_{N} 2\right)$ between commercial benzyl bromides and sodium azide $\left(\mathrm{NaN}_{3}\right)$. The benzyl azides obtained were oil-like liquids that were deemed suitable for use in subsequent reactions without further purification. These organic azides were then subjected to click chemistry with propargyl quinazolinones $(\mathbf{2} \mathbf{a}, \mathbf{b})$ in the presence of sodium L-ascorbate and $\beta$ cyclodextrin (CD), acting as reducing agent and phase-transfer catalyst, respectively, for $48-72 \mathrm{~h}$ to yield $4 \mathrm{a}-\mathrm{j}$ in low to excellent yields (30 - 89\%) after purification by trituration with both EtOH and distilled $\mathrm{H}_{2} \mathrm{O}$.

Successful syntheses of all compounds were confirmed by routine molecular characterization techniques, including infrared (IR), nuclear magnetic resonance (NMR) and high-resolution mass spectroscopy (HRMS). The ${ }^{1} \mathrm{H}$ and ${ }^{13} \mathrm{C}$ NMR spectra were inspected in order to identify peaks that are characteristic of quinazolinone, styryl and triazole moieties. The IR spectra were similarly investigated for the presence of characteristic absorptions that would allow for the identification of functional groups and substituents. 
The ${ }^{1} \mathrm{H}$ spectra of compounds $\mathbf{1} \mathbf{a}, \mathbf{b}$ bore a characteristic singlet peak around $\delta 12.00 \mathrm{ppm}$, indicative of proton $\mathrm{H}-3$ of the amide of quinazolinone ring. The disappearance of this peak in the spectra of compounds $\mathbf{2} \mathbf{a}, \mathbf{b}$ was confirmative of successful propargylation, further corroborated by the appearance of peaks that were indicative of propargyl protons. These included the doublet (d) of methylene $\mathrm{CH}_{2}, \mathrm{H}-1^{\prime \prime}$ (ca. $5.20 \mathrm{ppm}$ ) and the triplet $(\mathrm{t})$ of alkyne proton $\mathrm{H}-3^{\prime \prime}$ (ca. $\delta 3.24 \mathrm{ppm}$ ), respectively. Long-range coupling, ${ }^{4} \mathrm{~J} 2.3-2.4 \mathrm{~Hz}$, typical between alkyne protons was seen to occur between $\mathrm{H}-3^{\prime \prime}$ and $\mathrm{H}-\mathbf{1}^{\prime \prime}$ in the spectra of $2 \mathbf{2 a}, \mathbf{b} .^{28}$ The formation of the propargyl moiety was also indicated by the appearance of three additional peaks in the ${ }^{13} \mathrm{C}$ spectra of $\mathbf{2 a , b}$. These peaks were representative of the propargyl carbons C-1" (ca. $\delta 31.7 \mathrm{ppm}$ ), C-2" ( $\delta 79.0$ ppm) and C-3" (ca. $\delta 75.0$ ppm).

The appearance of two doublets (d) in the ${ }^{1} \mathrm{H}$ spectra of all quinazolinones provided evidence of the vinylic protons $\mathrm{H}-2^{\prime}\left(\delta\right.$ 8.00-7.85 ppm) and ${\mathrm{H}-1^{\prime}}^{\prime}(\delta$ 7.63-6.86 ppm) of the styryl moiety.

The literature reports ${ }^{3} \mathrm{~J}_{\mathrm{H}-\mathrm{H}} 12-18 \mathrm{~Hz}$ values for vinylic hydrogens in trans-configuration, while those of the cis-configuration have ${ }^{3} \mathrm{~J}_{\mathrm{H}-\mathrm{H}}$ in the $0-12 \mathrm{~Hz}$ range. ${ }^{28}$ The ${ }^{3} \mathrm{~J}_{\mathrm{H}-1^{\prime}-\mathrm{H}-2^{\prime}}$ values of the vinylic protons in the styryl moiety were found in the $15-16 \mathrm{~Hz}$ range, which suggested that the styryl moiety had occurred as the transisomer in all the quinazolinones synthesized. The $J$ values of the proton $\mathrm{H}-5$ (in the vicinity of the carbonyl) indicated $o$-coupling with proton $\mathrm{H}-6\left({ }^{3} \mathrm{~J}_{\mathrm{H}-5-\mathrm{H}-6} 6.7-7.9 \mathrm{~Hz}\right)$ and $m$-coupling with proton $\mathrm{H}-7\left({ }^{4} J_{\mathrm{H}-5-\mathrm{H}-7} 0.8-1.3 \mathrm{~Hz}\right) .{ }^{28}$

The spectra of intermediates 3a-e commonly had the singlets assigned to the resonance of methylene $\left(\mathrm{CH}_{2}\right)$ protons in the $\delta 4.50-4.30 \mathrm{ppm}$ region, and associated carbon in $\delta$ 54.9-53.5 ppm of the benzyl moiety. Additionally, the peaks resulting from the resonance of the aromatic protons were present in the spectra as doublets $(\mathrm{d})$ or triplet $(\mathrm{t})$ with an 0 -coupling $\left({ }^{3} \mathrm{~J}_{\mathrm{H}-3-\mathrm{H}-4} 7.4-8.5 \mathrm{~Hz}\right)$ among them. For $3 \mathrm{c}$, however, due to the fluoro-coupling, the signals of the protons adjacent to the fluorine resulted in a doublet of doublet (dd) with J 8.5, $5.3 \mathrm{~Hz}$ (o-coupling ${ }^{3} J_{\mathrm{H}-\mathrm{H}} 8.5$ and F-coupling ${ }^{3} \mathrm{~J}_{\mathrm{H}-\mathrm{F}} 5.3 \mathrm{~Hz}$ ).

The successful formation of the 1,2,3-triazole moiety was confirmed with the disappearance of the aforementioned propargyl peaks and the appearance of singlets representative of the triazolyl proton ( $\left.\mathrm{H}-5^{\prime \prime}\right)$ $(\delta 8.28-8.05 \mathrm{ppm})$ and carbon $\left(C-5^{\prime \prime}\right)(\delta 124.2-123.1 \mathrm{ppm})$ in the spectra of $4 \mathrm{a}-\mathrm{j}$. Another signal in the ${ }^{13} \mathrm{C}$ spectra of 4a-j that occurred in the region of $\delta 134.81-132.37 \mathrm{ppm}$, was indicative of the triazolyl carbon C4 ". This ring was also flanked on either side by methylene bridges bearing protons $\mathrm{H}-6^{\prime \prime} / \mathrm{H}-7^{\prime \prime}$ and carbons $\mathrm{C}-$ $6^{\prime \prime} / \mathrm{C}-7^{\prime \prime}$. The peaks associated with these tethers occurred in the regions of $\delta 5.73-5.57 \mathrm{ppm}\left(\mathrm{H}-7^{\prime \prime}\right), \delta 5.63-$ $5.48 \mathrm{ppm}\left(\mathrm{H}-6^{\prime \prime}\right), \delta 55.32-51.84 \mathrm{ppm}\left(\mathrm{C}-7^{\prime \prime}\right)$ and $\delta 38.16-37.87 \mathrm{ppm}\left(\mathrm{C}-6^{\prime \prime}\right)$.

Further confirmation of the structures of compounds $\mathbf{1 b} \mathbf{b} \mathbf{2} \mathbf{b}$ and $\mathbf{4 f - j}$ was indicated by the presence of the singlets representative of the methoxy (OMe) protons (ca. $\delta 3.80 \mathrm{ppm}$ ) and carbon in the $\delta 55.0-51.6 \mathrm{ppm}$ in their ${ }^{1} \mathrm{H}$ and ${ }^{13} \mathrm{C}$ spectra. Additional evidence of the structure of hybrid $4 \mathbf{j}$ was provided by the presence of the singlets attributed to the methyl (Me) protons, and the associated carbon at $\delta 2.22$ and 20.6 ppm, in their respective NMR spectra. These peaks were also seen in the spectra of $4 \mathrm{e}$ at $\delta 2.25$ for the methyl protons and at $\delta 20.1 \mathrm{ppm}$ for the carbon atom.

Characteristic absorptions for carbonyl functional groups $(C=O)\left(1672-1654 \mathrm{~cm}^{-1}, \mathrm{C}=\mathrm{O}\right.$ stretching) and $\mathrm{N}-\mathrm{H}$ portion of the amide (3186-3182 $\mathrm{cm}^{-1}, \mathrm{~N}-\mathrm{H}$ stretching) were seen in the IR spectra of 1a,b. Additionally, absorptions were observed for the propargyl $\left(3235-3209 \mathrm{~cm}^{-1}, \equiv \mathrm{C}-\mathrm{H}\right.$ stretching and $2115-2115 \mathrm{~cm}^{-1}, \mathrm{C} \equiv \mathrm{C}$ stretching) functional group in the IR spectra of $\mathbf{2 a , b}$. Other absorptions, specifically those pertaining to the $\mathrm{C}=\mathrm{N}\left(1642-1631 \mathrm{~cm}^{-1}, \mathrm{C}=\mathrm{N}\right.$ stretching) functionality, could be seen in the spectra of most quinazolinones. The absorption resulting from $\mathrm{N}=\mathrm{N}=\mathrm{N}$ stretching of the azido $\left(\mathrm{N}_{3}\right)$ functional group was present in the spectra of the intermediates 3a-e as a strong band in the $2100-2090 \mathrm{~cm}^{-1}$ region. The disappearance of this band from the spectra of hybrids $\mathbf{4 a - j}$ is another telltale sign of the successful click chemistry. 
The $\mathrm{C}=\mathrm{N}$ stretching absorptions of compounds $\mathbf{4 a}, \mathbf{4 h}$ and $\mathbf{4 i}$, however, were not visible due to the overlapping with those of their respective carbonyl $(\mathrm{C}=\mathrm{O})$ functional groups. The $\mathrm{C}-\mathrm{H}$ bending absorptions of the methylene bridges in compounds $2 \mathbf{a}, \mathbf{b}$ and $4 \mathbf{a}-\mathbf{j}$ occurred between $1473-1469 \mathrm{~cm}^{-1}$. Nitro $\left(\mathrm{NO}_{2}\right)$ and alkyl aryl ether functional groups were observed to absorb ca. $1519 \mathrm{~cm}^{-1}$ (N-O stretching), and $1256-1245 \mathrm{~cm}^{-1}$ (C-O stretching), respectively. Absorptions specific to the 1,2,3-triazole moiety were also observed; these included alkene $=\mathrm{C}-\mathrm{H}$ stretching in the region of $3140-3108 \mathrm{~cm}^{-1}$ and $\mathrm{C}-\mathrm{N}$ stretching in the $1348-1331 \mathrm{~cm}^{-1}$ range.

\section{Physicochemical properties}

The drug-likeness of the compounds was determined using Lipinski's rule of five, an index that is often adopted to predict whether a compound may be orally active in humans. ${ }^{29}$ Due consideration was given to oral activity as miltefosine is currently the only antileishmanial drug that is administered orally, and its use is threatened by toxicity and pathogenic resistance. This makes research into potentially orally active agents an imperative necessity. Thus, physicochemical properties, such as lipophilicity and aqueous solubility of the quinazolinone-triazole hybrids and their intermediates, were elaborated on and discussed as impactors of Lipinski's index (Table 1).

Table 1. Physicochemical properties and Lipinski's Rule of Five results of all synthesized quinazolinone derivatives as predicted by the SwissADME web tool, http://www.swissadme.ch

\begin{tabular}{|c|c|c|c|c|c|c|c|c|}
\hline \multirow{2}{*}{ Compd. } & \multirow{2}{*}{$\begin{array}{c}\mathrm{MW} \\
(\mathrm{g} / \mathrm{mol})\end{array}$} & \multirow{2}{*}{$c \log \mathrm{P}^{\mathrm{a}}$} & \multicolumn{2}{|c|}{$\log ^{b}$} & \multirow{2}{*}{$\mathrm{HBD}^{\mathrm{e}}$} & \multirow{2}{*}{ HBA $^{f}$} & \multirow{2}{*}{$\begin{array}{l}\text { Lipinski's } \\
\text { violation }\end{array}$} & \multirow{2}{*}{$\begin{array}{c}\text { Drug-like } \\
\text { /orally active }\end{array}$} \\
\hline & & & $\mathrm{ESOL}^{\mathrm{c}}$ & $A^{i}{ }^{d}$ & & & & \\
\hline $1 a$ & 248.28 & 3.16 & -3.92 & -3.89 & 1 & 2 & 0 & Yes \\
\hline $1 b$ & 278.31 & 3.13 & -3.97 & -4.06 & 1 & 3 & 0 & Yes \\
\hline $2 a$ & 286.33 & 3.44 & -3.89 & -3.47 & 0 & 2 & 0 & Yes \\
\hline $2 b$ & 316.35 & 3.43 & -3.95 & -3.63 & 0 & 3 & 0 & Yes \\
\hline $4 a$ & 464.48 & 3.29 & -5.15 & -5.71 & 0 & 6 & 0 & Yes \\
\hline $4 b$ & 498.37 & 4.53 & -6.00 & -5.64 & 0 & 4 & 0 & Yes \\
\hline $4 c$ & 437.47 & 4.24 & -5.25 & -5.03 & 0 & 5 & 0 & Yes \\
\hline $4 d$ & 419.48 & 3.89 & -5.09 & -4.92 & 0 & 4 & 0 & Yes \\
\hline $4 e$ & 433.50 & 4.28 & -5.40 & -5.31 & 0 & 4 & 0 & Yes \\
\hline $4 f$ & 494.50 & 3.23 & -5.22 & -5.87 & 0 & 7 & 0 & Yes \\
\hline $4 g$ & 528.40 & 4.63 & -6.07 & -5.80 & 0 & 5 & 1 & Yes \\
\hline $4 h$ & 467.49 & 4.31 & -5.32 & -5.19 & 0 & 6 & 0 & Yes \\
\hline $4 i$ & 449.50 & 3.91 & -5.16 & -5.09 & 0 & 5 & 0 & Yes \\
\hline $4 j$ & 463.53 & 4.35 & -5.46 & -5.47 & 0 & 5 & 0 & Yes \\
\hline
\end{tabular}

${ }^{a}$ Calculated $\log \mathrm{P}$ (consensus $\log \mathrm{P}$ ). ${ }^{\mathrm{b}}$ Predicted aqueous solubility, where $\log \mathrm{S}$ is the logarithm of the amount of compound (in moles) able to dissolve in a liter of water. ${ }^{\mathrm{C}} \mathrm{ESOL}=$ estimated aqueous solubility, calculated

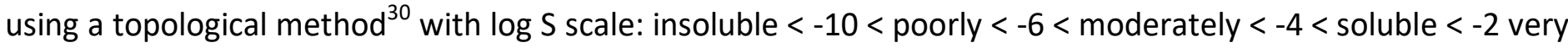
soluble $<0$ or more - highly soluble. ${ }^{\mathrm{d}}$ Calculated using a topological method. ${ }^{31}$ e Number of hydrogen bond donors ( $\mathrm{NH}$ and $\mathrm{OH}$ groups). ${ }^{\mathrm{f}}$ Number of hydrogen bond acceptors (nitrogen and oxygen atoms). ${ }^{\mathrm{g}}$ Determined with reference to Lipinski's rule of five ( $\mathrm{MW} \leq 500 \mathrm{~g} / \mathrm{mol}$; $\mathrm{CLOgP} \leq 5 ; \mathrm{HBD} \leq 5$; HBA $\leq 10$; no more than one violation allowed). ${ }^{29}$ All values in this table were calculated using the SwissADME web tool, http://www.swissadme.ch ${ }^{32}$ 
As can be seen in Table 1, the synthesized compounds had the physicochemical properties well within the target ranges as set by Lipinski et al. ${ }^{29}$ With the exception of $\mathbf{4 g}$, none of the compounds violate Lipinski's rules, predicting these quinazolinones to be drug-like in nature, suitable for oral administration, and well absorbed in the gastrointestinal tract through passive diffusion.

\section{Biological activity}

A single-point screening of all synthesized compounds, in $100 \mu \mathrm{M}$ concentration experiments, was performed to assess the antileishmanial activity against three strains of Leishmania promastigotes, with amphotericin B (AMB) serving as the reference drug. These strains were $L$. donovani strains (1S and 9515) and $L$. major strain IR-173. The Leishmania spp. were selected in order to determine the specificity of the synthesized compounds against $L$. major parasites that cause $C L$, and $L$. donovani parasites that communicate the more serious and debilitating VL. ${ }^{33}$

In this study, the quinazolinone derivatives were screened against the $L$. promastigotes in a two-stage process, involving the determination of the parasite growth inhibition percentage at the single (100 $\mu \mathrm{M})$ concentration, followed by the activity assessment through minimum inhibitory concentration (IC $\left.C_{50}\right)$ determination, for those compounds that fulfilled the growth inhibition criteria to be screened further for anti-promastigote activity. The cytotoxicity profiles of the quinazolinones were evaluated, using Vero cells with emetine (EM), known for its high toxicity, as a positive control. The biological results are presented in Table 2.

Table 2. In vitro anti-promastigote growth inhibition efficacy and cytotoxicity of quinazolinone derivatives at $100 \mu \mathrm{M}$ concentration

\begin{tabular}{|c|c|c|c|c|}
\hline \multirow{2}{*}{ Compd. } & \multicolumn{3}{|c|}{ Growth inhibition (\%) $^{\mathrm{a}}$} & \multirow{2}{*}{$\begin{array}{c}\text { Cytotoxicity, } \mathrm{IC}_{50} \pm \mathrm{SD}(\mu \mathrm{M})^{\mathrm{b}} \\
\text { Vero }^{\mathrm{c}}\end{array}$} \\
\hline & L. donovani $1 \mathrm{~S}$ & L. donovani 9515 & L. major IR-173 & \\
\hline $1 a$ & 28 & 2 & 13 & $>100$ \\
\hline $1 b$ & 0 & 21 & 14 & $>100$ \\
\hline $2 a$ & 58 & 44 & 24 & $>100$ \\
\hline $2 b$ & 0 & 0 & 0 & $>100$ \\
\hline $4 a$ & 0 & 0 & 9 & $>100$ \\
\hline 4b & 22 & 34 & 48 & $>100$ \\
\hline 4c & 0 & 0 & 1 & $>100$ \\
\hline $4 d$ & 0 & 13 & 0 & $>100$ \\
\hline $4 e$ & 0 & 15 & 26 & $>100$ \\
\hline $4 f$ & 0 & 0 & 2 & $>100$ \\
\hline $4 g$ & 0 & 0 & 3 & $>100$ \\
\hline $4 h$ & 0 & 0 & 0 & $>100$ \\
\hline $4 i$ & 0 & 0 & 20 & $>100$ \\
\hline $4 j$ & 0 & 0 & 8 & $>100$ \\
\hline AMB & 100 & 100 & 100 & $57.8 \pm 3.2$ \\
\hline EM & - & - & - & $0.05 \pm 0.004$ \\
\hline
\end{tabular}

Expressed as a mean percentage from duplicate biological experiments. ${ }^{\mathrm{b}}$ represented as the mean \pm the standard deviation (SD) from the triplicate biological experiments. ${ }^{c}$ African green monkey kidney epithelial cells. AMB: Amphotericin B deoxycholate; EM: Emetine dihydrochloride hydrate. 
Only three compounds, $\mathbf{1 a}, \mathbf{2} \mathbf{a}$ and $\mathbf{4 b}$, were observed to possess activity against the L. donovani $1 S$ strain. Substitution of a propargyl moiety at N-3 position of 1a (27\%) effectively doubled the antileishmanial activity against the $1 \mathrm{~S}$ strain, as evidenced by the activity of $\mathbf{2 a}(58 \%)$. The antileishmanial activity of $\mathbf{4 b}(22 \%)$ against L. donovani $1 \mathrm{~S}$ was structure specific, as no other hybrid had activity against this strain. None of the compounds with a methoxy $\left(\mathrm{CH}_{3} \mathrm{O}\right)$ substituent had activity against this strain.

The replacement of $\mathrm{H}\left(\mathrm{R}^{1}\right)$ in 1 a (2\%) with the electron-donating $\mathrm{CH}_{3} \mathrm{O}$ group was seen to have the effect of improving its activity against the L. donovani 9515 strain, as demonstrated by the markedly increased parasite growth-inhibitory activity of compound $\mathbf{1 b}$ (21\%). Conversely, unsubstituted counterparts, i.e., 2a, $\mathbf{4 b}$, $\mathbf{4 d}$ and $\mathbf{4 e}$, were active against $L$. donovani 9515 promastigotes. The activities of $\mathbf{4 b}, \mathbf{4 d}$ and $\mathbf{4 e}$ appeared to be structure specific, as no observable structure-activity relationship could be discerned between the net electronic effect [electron-withdrawing (EW) or electron-donating, (ED)] of their $\mathrm{R}^{2}$ substituents and the ability to inhibit the growth of $L$. donovani 9515 promastigotes.

Amongst compounds $4 \mathrm{a}-\mathrm{j}$, the greatest inhibition of $L$. donovani 9515 promastigote growth was seen to be elicited by $\mathbf{4 b}(34 \%)$ that had no $\mathrm{R}^{1}$ substituent and possessed a bromine as $\mathrm{R}^{2}$ substituent. Overall, compound 2a (43\%) was observed to be the most active quinazolinone against $L$. donovani 9515 . L. major promastigotes appeared to be more susceptible to the synthesized compounds than were the $L$. donovani parasites. Most of the compounds were observed to exhibit some degree of growth inhibitory activity against L. major IR-173 strain promastigotes, with the exception of $\mathbf{2} \mathbf{b}, \mathbf{4} \mathbf{d}$ and $\mathbf{4 h}$. Overall, the greatest inhibitor of L. major IR-173 promastigote growth was observed to be hybrid $\mathbf{4 b}$ (47\%).

The literature suggested a $70 \%$ parasite growth inhibition threshold at $10 \mu \mathrm{M}$ for antileishmanial $I C_{50}$ determinations. ${ }^{33}$ We were compelled to use $100 \mu \mathrm{M}$ in order to identify qualifying compounds as $10 \mu \mathrm{M}$ screening produced nearly no inhibition. As no synthesized compounds had reached the $70 \%$ inhibition threshold, we subsequently also lowered, and arbitrarily set, a new threshold at $25 \%$ to allow for more quinazolinones qualifying for $\mathrm{IC}_{50}$ determinations. Thus, the intermediate compounds $\mathbf{1} \mathbf{b}$ and $\mathbf{2} \mathbf{a}$, and the hybrids $\mathbf{4 b}$ and $\mathbf{4 e}$, all with parasite growth inhibition higher than $25 \%$ regardless of the strain, were selected for $\mathrm{IC}_{50}$ determinations. They were also non-cytotoxic to Vero cells $\left(\mathrm{IC}_{50}>100 \mu \mathrm{M}\right) .{ }^{34}$ They were also found to be inactive against all three Leishmania promastigotes strains with $\mathrm{IC}_{50}>100 \mu \mathrm{M}$.

All synthesized compounds were screened as suspensions in aqueous growth medium. The poor aqueous solubility may have, in part, contributed to the lack of antileishmanial activity and cytotoxicity.

\section{Conclusions}

A small library of quinazolinone derivatives were synthesized in low to good yields (30 - 89\%) using a variety of synthetic methods, including cyclization, condensation, nucleophilic $\left(\mathrm{S}_{\mathrm{N}} 2\right)$ substitution and copper-catalyzed alkyne-azide cycloaddition (CUAAC) reactions. The in vitro antileishmanial activity and cytotoxicity of the compounds were determined against three strains of Leishmania promastigotes and Vero cells, respectively.

The compounds were nontoxic to the mammalian cells, but also had only moderate-to-no antileishmanial activities despite meeting predicted drug-like criteria. The complete lack of cytotoxicity and the inability to adequately inhibit promastigote growth may be attributed to the poor aqueous solubility of the compounds. Two derivatives stood out, however, as they were observed to possess moderate antileishmanial activity. These were 2a featuring styryl and propargyl moieties with 43 - 58\% growth inhibition of L. donovani, and hybrid 4b containing 4-methoxystyryl and propargyl moieties with $48 \%$ growth inhibition of L. major promastigotes. No conclusive structure-activity relationship could be deduced from this study. Future studies 
may include the investigation of more water-soluble derivatives in order to address the antileishmanial inactivity issue encountered in the study.

\section{Experimental Section}

General. All reagents were purchased from Sigma-Aldrich (Johannesburg, South Africa). Ammonium acetate and $\mathrm{N}, \mathrm{N}$-dimethylformamide (DMF) were purchased from Merck (Johannesburg, South Africa). All other solvents, and magnesium sulphate, were purchased from Associated Chemical Enterprises Acetone (Johannesburg, South Africa). All chemicals and reagents were reagent/analytical grade and were used without further purification.

The ${ }^{1} \mathrm{H}$ and ${ }^{13} \mathrm{C}$ NMR spectra of all 14 compounds were recorded on a Bruker Avance III 600 spectrometer at frequencies of $600 \mathrm{MHz}\left({ }^{1} \mathrm{H} \mathrm{NMR}\right)$ and $150.913\left({ }^{13} \mathrm{C} \mathrm{NMR}\right)$, respectively, in deuterated dimethyl sulfoxide (DMSO- $\left.d_{6}\right)$ at room temperature $\left(\sim 25^{\circ} \mathrm{C}\right)$ or, alternatively, $80^{\circ} \mathrm{C}$, where indicated. Chemical shifts in spectra obtained were expressed and reported in parts per million $\delta(\mathrm{ppm})$, with the residual protons of the deuterated solvents serving as the reference. J (coupling constant) values were expressed in $\mathrm{Hertz}(\mathrm{Hz})$. Abbreviations used to indicate splitting patterns were as follows: singlet (s), doublet (d), doublet of doublets $(\mathrm{dd})$, triplet (t), triplet of doublets (td), and multiplet $(\mathrm{m})$.

HRMS spectra were recorded on a micrOTOF-Q II mass spectrometer, using an APCI source type heated at 200 ${ }^{\circ} \mathrm{C}$. The software used to record the mass spectra was the Bruker Compass DataAnalaysis 4.0 software package. Scans were performed from $50-1600 \mathrm{~m} / \mathrm{z}$ at a capillary voltage of 4500 volts (V), an end-plate-offset voltage of $-500 \mathrm{~V}$, with the nebulizer set at $1.6 \mathrm{Bar}$, and a collision cell radio frequency (RF) voltage of 100 volts peak to peak (Vpp).

High-performance liquid chromatography (HPLC) was carried out on all compounds to determine their purity. Full description of the process can be found in the Supplementary Material file.

Infrared (IR) spectra were recorded on a Bruker Alpha-P FTIR instrument system.

Thin-layer chromatography (TLC) was performed using aluminium-backed silica gel plates from Merck (Johannesburg, South Africa) with a mean pore size of $60 \AA$ with added fluorescent indicator (F254). TLC plates were visualized at $254 \mathrm{~nm}$.

Melting points of all compounds were performed on a Büchi melting point B-545 apparatus and are uncorrected.

\section{Synthesis of 2-(4-substituted styryl)-4(3H)-quinazolinones $1 \mathrm{a}, \mathrm{b}$}

Compounds $1 \mathbf{a}, \mathbf{b}$ were synthesized through a known method reported by Kumar et al. ${ }^{25}$ and illustrated in Scheme 1 ( $\mathrm{i}$ - ii). The method was carried out as follows: To a mixture of isatoic anhydride $(8.16 \mathrm{~g}, 0.05 \mathrm{~mol})$ and ammonium acetate $(3.85 \mathrm{~g}, 0.05 \mathrm{~mol})$, in a flask outfitted with a magnetic stirrer, was added an equimolar amount of triethyl orthoacetate $(8.11 \mathrm{~g}, 0.05 \mathrm{~mol})$. The mixture was refluxed for $6-8 \mathrm{~h}$. Afterwards, the appropriate para-substituted benzaldehyde $(0.05 \mathrm{~mol})$ was added and refluxing was continued for another 6 $8 \mathrm{~h}$ until TLC monitoring showed completion of the reaction. The content of the flask was then suspended in a suitable amount of EtOH ( $25 \mathrm{~mL}$ ), boiled and filtered. The crude residue was further purified by precipitation. It was heated ca. $150{ }^{\circ} \mathrm{C}$ in DMF $(100 \mathrm{~mL})$ with stirring, and solubilized until a clear solution was obtained. The solution was then slowly poured into $\mathrm{H}_{2} \mathrm{O}(100 \mathrm{~mL})$ with stirring at room temperature. This resulted in the precipitation of compounds $\mathbf{1} \mathbf{a}, \mathbf{b}$ which were filtered off in a sintered glass funnel, washed with $\mathrm{H}_{2} \mathrm{O}(3 \times 150$ $\mathrm{mL}$ ) and dried in oven at $90{ }^{\circ} \mathrm{C}$. 
(E)-2-Styrylquinazolin-4(3H)-one (1a). The reaction involving benzaldehyde $(5.31 \mathrm{~g}, 0.05 \mathrm{~mol})$ resulted in $1 \mathrm{a}$ as a white powder (7.3 g, $0.03 \mathrm{~mol}, 60 \%$ ). m.p. $254.5-254.9{ }^{\circ} \mathrm{C}$ (precipitation in $\mathrm{H}_{2} \mathrm{O}$ ) (Lit., ${ }^{35} 251-253^{\circ} \mathrm{C}$ ).

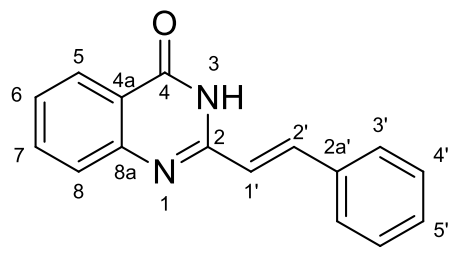

(E)-2-(4-Methoxystyryl)quinazolin-4(3H)-one (1b). The reaction involving 4-anisaldehyde $(6.81 \mathrm{~g}, 0.05 \mathrm{~mol})$ provided $\mathbf{1 b}$ as light-yellow powder (6.8 g, $0.03 \mathrm{~mol}, 50 \%$ ). m.p. $285.0-285.5{ }^{\circ} \mathrm{C}$ (precipitation in $\left.\mathrm{H}_{2} \mathrm{O}\right)\left(\mathrm{Lit}^{3}{ }^{35}\right.$ $\left.276-278{ }^{\circ} \mathrm{C}\right)$. There are significant differences between our data and that provided in the literature.

IR $v_{\max }\left(\mathrm{cm}^{-1}\right): 3182(\mathrm{~N}-\mathrm{H})(\mathrm{w}), 1671(\mathrm{C}=\mathrm{O})(\mathrm{s}), 1642(\mathrm{C}=\mathrm{N})(\mathrm{m}) .{ }^{1} \mathrm{H}$ NMR $\left(600 \mathrm{MHz}, \mathrm{DMSO}-d_{6}, 80^{\circ} \mathrm{C}\right) \delta(\mathrm{ppm}):$ 11.98 (s, 1H, H-3), 8.12 (dd, J 7.5, $1.3 \mathrm{~Hz}, 1 \mathrm{H}, \mathrm{H}-5), 7.91$ (d, J $\left.16.1 \mathrm{~Hz}, 1 \mathrm{H}, \mathrm{H}-2^{\prime}\right), 7.78$ (td, J 8.3, 1.3 Hz, 1H, H-7), 7.65 (d, J $8.3 \mathrm{~Hz}, 1 \mathrm{H}, \mathrm{H}-8$ ), 7.61 (d, J $\left.8.7 \mathrm{~Hz}, 2 \mathrm{H}, \mathrm{H}-3^{\prime}\right), 7.45$ (t, J $\left.7.5 \mathrm{~Hz}, 1 \mathrm{H}, \mathrm{H}-6\right), 7.03$ (d, J $\left.8.7 \mathrm{~Hz}, 2 \mathrm{H}, \mathrm{H}-4^{\prime}\right), 6.86$ (d, J $\left.16.1 \mathrm{~Hz}, 1 \mathrm{H}, \mathrm{H}-1^{\prime}\right), 3.84\left(\mathrm{~s}, 3 \mathrm{H}, \mathrm{H}-6^{\prime}\right) .{ }^{13} \mathrm{C}$ NMR (151 MHz, DMSO-d $\left.6,80{ }^{\circ} \mathrm{C}\right) \delta(\mathrm{ppm}): 161.3(\mathrm{C}-4), 160.3(\mathrm{C}-$ 5'), 151.4 (C-2), 148.7 (C-8a), 137.6 (C-2'), 133.8 (C-7), 128.7 (C-3'), 127.5 (C-2a'), 126.5 (C-6), 125.4 (C-8), 125.3 (C-5), 120.7 (C-4a), 118.48 (C-1'), 114.2 (C-4'), 55.0 (C-6'). HRMS-APCl m/z $[\mathrm{M}+\mathrm{H}]^{+}$calcd for $\mathrm{C}_{17} \mathrm{H}_{14} \mathrm{~N}_{2} \mathrm{O}_{2}{ }^{+}$ 279.1134, found 279.1117. Purity: 96\%.

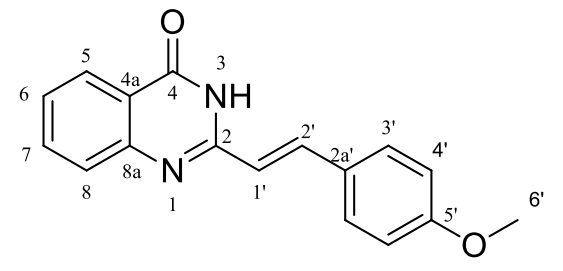

\section{Synthesis of 3-propynyl-2-(4-substituted styryl)-4(3H)-quinazolinones $2 a, b$}

Compounds $\mathbf{2} \mathbf{a}-\mathbf{b}$ were synthesized using a literature method ${ }^{26}$ as illustrated in Scheme 1 (iii). The synthesis is described as follows: Propargyl bromide $(2.86 \mathrm{~g}, 0.024 \mathrm{~mol})$ was added to a suspension of the appropriate intermediate 2-(4-substituted styryl)-4(3H)-quinazolinone, 1a,b $(0.02 \mathrm{~mol}$ ) and potassium carbonate (33.17 g, $0.24 \mathrm{~mol}$ ) in DMF $(50 \mathrm{~mL})$. The reaction mixture was allowed to stir at room temperature until TLC monitoring indicated complete disappearance of the intermediate (15 min - $48 \mathrm{~h}$ ). The content of the flask was then poured into distilled water at room temperature and stirred until complete dissolution of the potassium carbonate. This results in the formation of precipitate that was filtered off, washed with distilled water ( $3 \mathrm{x}$ $50 \mathrm{~mL}$ ), thoroughly dried, and recrystallized from acetone or EtOH to afford the target compound.

(E)-3-(Prop-2-yn-1-yl)-2-styrylquinazolin-4(3H)-one (2a). The reaction involving (E)-2-Styrylquinazolin-4(3H)one ${ }^{37}$, 1a (4.97 g, 0.02 mol) afforded 2a as light-yellow needle-shaped crystals (3.1 g, $\left.0.01 \mathrm{~mol}, 44 \%\right)$. m.p. 181.3-82.3 ${ }^{\circ} \mathrm{C}$ (from acetone). IR $v_{\max }\left(\mathrm{cm}^{-1}\right): 3209(\equiv \mathrm{C}-\mathrm{H})(\mathrm{s}), 2115(\mathrm{C} \equiv \mathrm{C})(\mathrm{w}), 1665(\mathrm{C}=\mathrm{O})(\mathrm{s}), 1633(\mathrm{C}=\mathrm{N})(\mathrm{m})$, $1470\left(\mathrm{CH}_{2}, \mathrm{C}-\mathrm{H}\right)(\mathrm{m}) .{ }^{1} \mathrm{H}$ NMR $\left(600 \mathrm{MHz}, \mathrm{DMSO}-d_{6}, 80^{\circ} \mathrm{C}\right) \delta(\mathrm{ppm}): 8.17(\mathrm{dd}, J 7.9,0.8 \mathrm{~Hz}, 1 \mathrm{H}, \mathrm{H}-5), 8.00(\mathrm{~d}, J$ $\left.15.3 \mathrm{~Hz}, 1 \mathrm{H}, \mathrm{H}-2^{\prime}\right), 7.84(\mathrm{td}, J$ 8.3, $0.8 \mathrm{~Hz}, 1 \mathrm{H}, \mathrm{H}-7), 7.79$ (d, J $\left.7.4 \mathrm{~Hz}, 2 \mathrm{H}, \mathrm{H}-3^{\prime}\right), 7.72(\mathrm{~d}, J 8.3 \mathrm{~Hz}, 1 \mathrm{H}, \mathrm{H}-8), 7.52(\mathrm{t}$, J $7.9 \mathrm{~Hz}, 1 \mathrm{H}, \mathrm{H}-6), 7.50-7.43\left(\mathrm{~m}, 4 \mathrm{H}, \mathrm{H}-1^{\prime}, \mathrm{H}-4^{\prime}, \mathrm{H}-5^{\prime}\right), 5.20$ (d, J $\left.2.4 \mathrm{~Hz}, 2 \mathrm{H}, \mathrm{H}-1^{\prime \prime}\right), 3.24$ (t, J 2.4 Hz, 1H, H-3").

${ }^{13} \mathrm{C}$ NMR (151 MHz, DMSO- $\left.d_{6}, 80{ }^{\circ} \mathrm{C}\right) \delta(\mathrm{ppm}): 160.1$ (C-4), 151.0 (C-2), 146.7 (C-8a), 139.98 (C-2'), 134.9 (C2a'), 134.2 (C-7), 129.3 (C-5'), 128.52 (C-4'), 127.5 (C-3'), 126.7 (C-6), 126.1 (C-8), 126.0 (C-5), 119.47 (C-4a), 
119.2 (C-1'), 78.6 (C-2"), 74.4 (C-3"), 31.7 (C-1"). HRMS-APCI m/z [M+H] ${ }^{+}$calcd for $\mathrm{C}_{19} \mathrm{H}_{14} \mathrm{~N}_{2} \mathrm{O}^{+} 287.1184$, found 287.1175. Purity: $98 \%$.

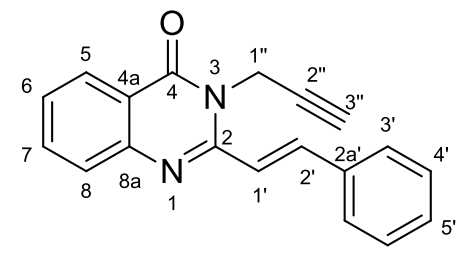

(E)-2-(4-Methoxystyryl)-3-(prop-2-yn-1-yl)-quinazolin-4(3H)-one (2b). The reaction involving (E)-2-(4methoxy-styryl)-quinazolin-4(3H)-one $\mathbf{1 b}(5.57 \mathrm{~g}, 0.02 \mathrm{~mol})$ provided $\mathbf{2 b}$ as yellow needle-shaped crystals (2.6 g, $0.008 \mathrm{~mol}, 40 \%)$. m.p. 190.6-191.2 ${ }^{\circ} \mathrm{C}$ (from EtOH). IR $v_{\max }\left(\mathrm{cm}^{-1}\right): 3235$ (三C-H) (s), $2114(\mathrm{C} \equiv \mathrm{C})(\mathrm{w}), 1659$ (C=O) (s), $1630(\mathrm{C}=\mathrm{N})(\mathrm{m}), 1468\left(\mathrm{CH}_{2}, \mathrm{C}-\mathrm{H}\right)(\mathrm{m}), 1245\left(\mathrm{O}-\mathrm{CH}_{3}\right)(\mathrm{s}) .{ }^{1} \mathrm{H}$ NMR $\left(600 \mathrm{MHz}, \mathrm{DMSO}-d_{6}, 80{ }^{\circ} \mathrm{C}\right) \delta(\mathrm{ppm}): 8.15$ (d, J $7.8 \mathrm{~Hz}, 1 \mathrm{H}, \mathrm{H}-5), 7.98$ (d, J $\left.15.2 \mathrm{~Hz}, 1 \mathrm{H}, \mathrm{H}-2^{\prime}\right), 7.82$ (t, J $\left.8.0 \mathrm{~Hz}, 1 \mathrm{H}, \mathrm{H}-7\right), 7.74$ (d, J $\left.8.6 \mathrm{~Hz}, 2 \mathrm{H}, \mathrm{H}-3^{\prime}\right), 7.69$ (d, J $8.0 \mathrm{~Hz}, 1 \mathrm{H}, \mathrm{H}-8), 7.50(\mathrm{t}, J 7.8 \mathrm{~Hz}, 1 \mathrm{H}, \mathrm{H}-6), 7.30$ (d, J $\left.15.2 \mathrm{~Hz}, 1 \mathrm{H}, \mathrm{H}-1^{\prime}\right), 7.05$ (d, J $\left.8.6 \mathrm{~Hz}, 2 \mathrm{H}, \mathrm{H}-4 \mathbf{4}^{\prime}\right), 5.18$ (d, J 2.3 $\left.\mathrm{Hz}, 2 \mathrm{H}, \mathrm{H}-1^{\prime \prime}\right), 3.85$ (s, 3H, H-6'), 3.22 (t, J $\left.2.3 \mathrm{~Hz}, 1 \mathrm{H}, \mathrm{H}-3^{\prime \prime}\right) .{ }^{13} \mathrm{C}$ NMR (151 MHz, DMSO-d $\left.6,80{ }^{\circ} \mathrm{C}\right) \delta(\mathrm{ppm}): 160.5$ (C-4), 160.1 (C-5'), 151.3 (C-2), 146.8 (C-8a), 139.8 (C-2'), 134.1 (C-7), 129.2 (C-3'), 127.7 (C-2a'), 126.6 (C-6), 126.0 (C-8), 125.8 (C-5), 119.3 (C-4a), 116.6 (C-1'), 114.2 (C-4'), 78.6 (C-2'), 74.3 (C-3'), 55.0 (C-6'), 31.7 (C-1'). HRMS-APCl $m / z[M+H]^{+}$calcd for $\mathrm{C}_{20} \mathrm{H}_{16} \mathrm{~N}_{2} \mathrm{O}_{2}{ }^{+} 317.1290$, found 317.1267. Purity (HPLC): $98 \%$.

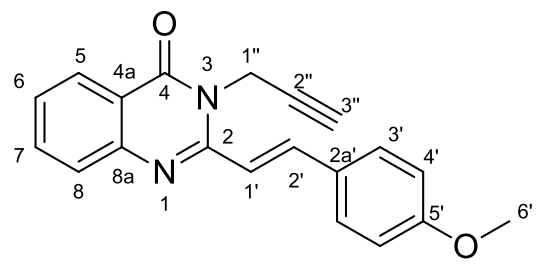

\section{Synthesis of para-substituted benzyl azides 3a-e}

Intermediates 3a-e were synthesized by employing a literature method ${ }^{27}$ as illustrated in Scheme 1 (iv). The appropriate para-substituted benzyl bromide $(0.01 \mathrm{~mol})$ was dissolved in DMSO $(20 \mathrm{~mL})$ in a flask outfitted with a magnetic stirrer. Sodium azide $(0.71 \mathrm{~g}, 0.011 \mathrm{~mol})$ was slowly added to the flask and the reaction mixture was stirred for $10-12 \mathrm{~h}$ at room temperature. Afterwards, the reaction was quenched with $\mathrm{H}_{2} \mathrm{O}(50$ $\mathrm{mL})$. The aqueous mixture was extracted with EtOAc $(3 \times 50 \mathrm{~mL})$. The organic phase was then washed with brine $(3 \times 50 \mathrm{~mL})$, dried overnight with $\mathrm{MgSO}_{4}$, and filtered off. The filtrate was evaporated under vacuum evaporator to produce 3a-e as oils which were used in subsequent syntheses without further purification.

1-(Azidomethyl)-4-nitrobenzene (3a). The reaction involving 1-(bromomethyl)-4-nitrobenzene (2.16 g, $0.01 \mathrm{~mol}$ ) provided $3 \mathrm{a}$ as reddish-orange oil $(1.9 \mathrm{~g}, 0.01 \mathrm{~mol}, 100 \%)$. IR $\mathrm{v}_{\max }\left(\mathrm{cm}^{-1}\right): 2102(\mathrm{~N}=\mathrm{N}=\mathrm{N})(\mathrm{s}) .{ }^{1} \mathrm{H} N M R$ $\left(600 \mathrm{MHz}, \mathrm{CDCl}_{3}\right) \delta(\mathrm{ppm}): 8.24$ (d, J $\left.8.5 \mathrm{~Hz}, 2 \mathrm{H}, \mathrm{H}-4\right), 7.50$ (d, J $\left.8.5 \mathrm{~Hz}, 2 \mathrm{H}, \mathrm{H}-3\right), 4.50(\mathrm{~s}, 2 \mathrm{H}, \mathrm{H}-1) .{ }^{13} \mathrm{C} \mathrm{NMR}(151$ $\mathrm{MHz}, \mathrm{CDCl}_{3}$ ) $\delta$ (ppm): 147.9 (C-5), 142.8 (C-2), 128.7 (C-3), 124.2 (C-4), 53.8 (C-1).

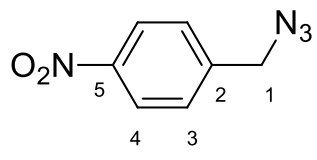

1-(Azidomethyl)-4-bromobenzene (3b). The reaction of 1-(bromomethyl)-4-bromobenzene $(2.5 \mathrm{~g}, 0.01 \mathrm{~mol})$ resulted in $\mathbf{3 b}$ as a clear oil $(2.2 \mathrm{~g}, 0.01 \mathrm{~mol}, 100 \%)$. IR $\mathrm{v}_{\max }\left(\mathrm{cm}^{-1}\right): 2093(\mathrm{~N}=\mathrm{N}=\mathrm{N})(\mathrm{s}) .{ }^{1} \mathrm{H} \mathrm{NMR}\left(600 \mathrm{MHz} \mathrm{CDCl}_{3}\right)$ 
$\delta$ (ppm): 7.51 (d, J $8.4 \mathrm{~Hz}, 2 \mathrm{H}, \mathrm{H}-4), 7.19$ (d, J $8.4 \mathrm{~Hz}, 2 \mathrm{H}, \mathrm{H}-3), 4.30(\mathrm{~s}, 2 \mathrm{H}, \mathrm{H}-1) .{ }^{13} \mathrm{C} \mathrm{NMR}(151 \mathrm{MHz}, \mathrm{CDCl}) \delta$ (ppm): 134.5 (C-2), 132.1 (C-3), 129.9 (C-4), 122.5 (C-5), 53.5 (C-1).

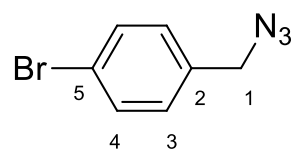

1-(Azidomethyl)-4-fluorobenzene (3c). The reaction of 1-(bromomethyl)-4-fluorobenzene (1.89 $\mathrm{g}, 0.01 \mathrm{~mol})$ afforded 3c as a yellow oil (1.1 g, $0.007 \mathrm{~mol}, 70 \%)$. IR $\mathrm{v}_{\max }\left(\mathrm{cm}^{-1}\right): 2093(\mathrm{~N}=\mathrm{N}=\mathrm{N})(\mathrm{s}) .{ }^{1} \mathrm{H} \mathrm{NMR}(600 \mathrm{MHz} \mathrm{CDCl}) \delta$ (ppm): 7.30 (dd, J 8.5, 5.3 Hz, 2H, H-4), $7.08(\mathrm{t}, J 8.5 \mathrm{~Hz}, 2 \mathrm{H}, \mathrm{H}-3), 4.32(\mathrm{~s}, 2 \mathrm{H}, \mathrm{H}-1) .{ }^{13} \mathrm{C} \mathrm{NMR}(151 \mathrm{MHz} \mathrm{CDCl})_{3} \delta$ (ppm): 162.8 (C-5), 131.3 (C-2), 130.2 (C-3), 115.9 (C-4), 54.2 (C-1).

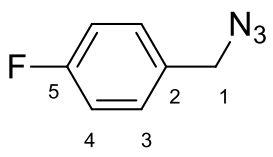

(Azidomethyl)benzene (3d). The reaction involving benzyl bromide (1.71 g, $0.01 \mathrm{~mol}$ ) provided 3d as a yellow oil (1.2 g, $0.009 \mathrm{~mol}, 90 \%)$. IR $\mathrm{v}_{\max }\left(\mathrm{cm}^{-1}\right): 2090(\mathrm{~N}=\mathrm{N}=\mathrm{N})(\mathrm{s}) .{ }^{1} \mathrm{H} \mathrm{NMR}\left(600 \mathrm{MHz}, \mathrm{CDCl}_{3}\right) \delta(\mathrm{ppm}):{ }^{1} \mathrm{H} \mathrm{NMR}(600$ $\mathrm{MHz}_{\mathrm{CDCl}}$ ) $\delta: 7.40$ (t, J $\left.7.4 \mathrm{~Hz}, 2 \mathrm{H}, \mathrm{H}-4\right), 7.35$ (t, J $\left.6.9 \mathrm{~Hz}, 1 \mathrm{H}, \mathrm{H}-5\right), 7.33$ (d, J $\left.7.4 \mathrm{~Hz}, 2 \mathrm{H}, \mathrm{H}-3\right), 4.35$ (s, 2H, H-1). ${ }^{13} \mathrm{C}$ NMR (151 MHz, CDCl 3 ) $\delta$ (ppm): 135.5 (C-2), 129.0 (C-4), 128.4 (C-5), 128.3 (C-3), 54.9 (C-1).

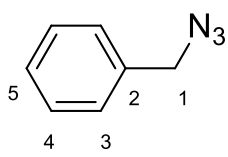

1-(Azidomethyl)-4-methylbenzene (3e). The reaction of 1-(bromomethyl)-4-methylbenzene (1.85 g, $0.01 \mathrm{~mol})$ afforded $3 e$ as a pale yellow oil $(1.4 \mathrm{~g}, 0.0095 \mathrm{~mol}, 95 \%)$. IR $\mathrm{v}_{\max }\left(\mathrm{cm}^{-1}\right): 2094(\mathrm{~N}=\mathrm{N}=\mathrm{N})(\mathrm{s}) .{ }^{1} \mathrm{H} \mathrm{NMR}(600 \mathrm{MHz}$, $\mathrm{CDCl}_{3}$ ) $\delta(\mathrm{ppm}): 7.22(\mathrm{~d}, J 8.3 \mathrm{~Hz}, 2 \mathrm{H}, \mathrm{H}-3), 7.20$ (d, J $\left.8.3 \mathrm{~Hz}, 2 \mathrm{H}, \mathrm{H}-4\right), 4.30(\mathrm{~s}, 2 \mathrm{H}, \mathrm{H}-1), 2.37$ (s, 3H, H-6). ${ }^{13} \mathrm{C}$ NMR (151 MHz, CDCl ${ }_{3}$ ) (ppm): 138.3 (C-2), 132.4 (C-5), 129.6 (C-4), 128.4 (C-3), 54.8 (C-1), 21.3 (C-6).

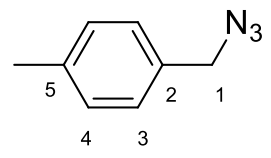

\section{Synthesis of quinazolinone-triazole hybrids 4a-j}

The compounds were synthesized according to a literature method, ${ }^{27}$ depicted in Scheme 1 ( $v$ ) and outlined as

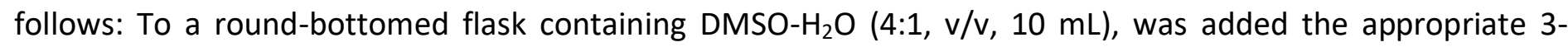
propyl-2-(4-substituted styryl)-4(3H)-quinazolinone $2 \mathrm{a}-\mathbf{b}(0.7 \mathrm{mmol})$, the appropriate benzyl azide 3a-e (0.77 $\mathrm{mmol}), \beta$-cyclodextrin $(0.06 \mathrm{~g}, 0.049 \mathrm{mmol})$, sodium L-ascorbate $(0.01 \mathrm{~g}, 0.21 \mathrm{mmol})$ and copper sulfate pentahydrate $(0.02 \mathrm{~g}, 0.07 \mathrm{mmol})$. The mixture was stirred at room temperature for $48-72 \mathrm{~h}$ until TLC monitoring revealed complete consumption of $\mathbf{2 a - b}$. Afterwards, the reaction mixture was precipitated in $\mathrm{H}_{2} \mathrm{O}$. The precipitate was filtered off, and thoroughly rinsed with $\mathrm{H}_{2} \mathrm{O}(3 \times 20 \mathrm{~mL})$ and $\mathrm{EtOH}(3 \times 20 \mathrm{~mL})$ and then dried in an oven at $70{ }^{\circ} \mathrm{C}$ for $2-3 \mathrm{~h}$ to yield compounds $4 \mathbf{4 a - j}$. 
(E)-3-\{[1-(4-Nitrobenzyl)-1H-1,2,3-triazol-4-yl]methyl\}-2-styrylquinazolin-4(3H)-one (4a). The reaction of $2 a$ $(0.2 \mathrm{~g}, 0.7 \mathrm{mmol})$ with $3 \mathrm{a}(0.14 \mathrm{~g}, 0.77 \mathrm{mmol})$ afforded $4 \mathrm{a}$ as a pale yellow powder $(0.17 \mathrm{~g}, 0.36 \mathrm{mmol}, 52 \%)$. m.p. 248.9-251.6 ${ }^{\circ} \mathrm{C}$ (precipitation in $\left.\mathrm{H}_{2} \mathrm{O}\right)$. IR $\mathrm{v}_{\max }\left(\mathrm{cm}^{-1}\right)$ : $3137(=\mathrm{C}-\mathrm{H})(\mathrm{w}), 1661$ (C=O) (s), $1519\left(\mathrm{NO}_{2}\right)(\mathrm{s}), 1342$ (C-N) (s). ${ }^{1} \mathrm{H}$ NMR (600 MHz, DMSO-d $\left.)_{6}\right) \delta(\mathrm{ppm}): 8.28\left(\mathrm{~s}, 1 \mathrm{H}, \mathrm{H}-5{ }^{\prime \prime}\right), 8.15$ (d, J 7.8 Hz, 1H, H-5), 8.06 (d, J $8.6 \mathrm{~Hz}$, $\left.2 \mathrm{H}, \mathrm{H}-9^{\prime \prime}\right), 7.88$ (d, J $\left.15.3 \mathrm{~Hz}, 1 \mathrm{H}, \mathrm{H}-2^{\prime}\right), 7.83(\mathrm{t}, J 7.6 \mathrm{~Hz}, 1 \mathrm{H}, \mathrm{H}-7), 7.71$ (d, J $\left.7.1 \mathrm{~Hz}, 2 \mathrm{H}, \mathrm{H}-3^{\prime}\right), 7.71$ (d, J $7.6 \mathrm{~Hz}$, 1H, H-8), 7.62 (d, J $\left.15.3 \mathrm{~Hz}, 1 \mathrm{H}, \mathrm{H}-1^{\prime}\right), 7.51$ (t, J $\left.7.8 \mathrm{~Hz}, 1 \mathrm{H}, \mathrm{H}-6\right), 7.44-7.38$ (m, 5H, H-4', H-5', H-8'), 5.73 (s, $\left.2 \mathrm{H}, \mathrm{H}-7^{\prime \prime}\right), 5.63$ (s, 2H, H-6"). ${ }^{13} \mathrm{C}$ NMR (151 MHz, DMSO-d $) \delta$ (ppm): 161.1 (C-4), 151.9 (C-2), 147.1 (C-8a), 147.0 (C-10"), 143.3 (C-7a"'), 143.2 (C-2'), 139.8 (C-2a'), 135.1 (C-7), 134.6 (C-4'), 129.7 (C-5'), 128.9 (C-8'), 128.8 (C-4'), 127.9 (C-3'), 127.0 (C-6), 126.5 (C-8), 126.4 (C-5), 124.2 (C-5”), 123.7 (C-9'), 120.0 (C-4a), 119.9 (C-1'), 51.8 (C-7") , 38.0 (C-6"). HRMS-APCI m/z [M+H] calcd for $\mathrm{C}_{26} \mathrm{H}_{20} \mathrm{~N}_{6} \mathrm{O}_{3}{ }^{+}$465.1675, found 465.1641. Purity (HPLC): $100 \%$.

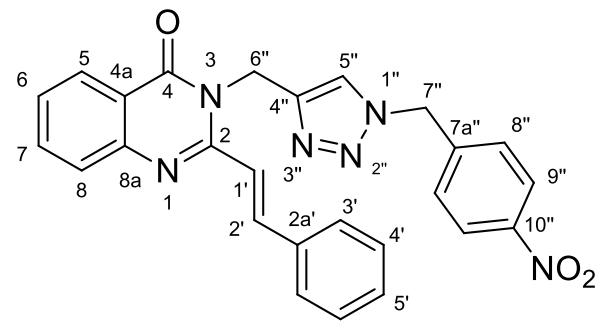

(E)-3-\{[1-(4-Bromobenzyl)-1H-1,2,3-triazol-4-yl]methyl\}-2-styrylquinazolin-4(3H)-one (4b). The reaction of $2 \mathrm{a}$ 2a $(0.20 \mathrm{~g}, 0.7 \mathrm{mmol})$ with $\mathbf{3 b}(0.16 \mathrm{~g}, 0.77 \mathrm{mmol})$ afforded $4 \mathrm{~b}$ as a light yellow-orange powder $(0.14 \mathrm{~g}, 0.27$ mmol, 38\%). m.p. $269.0-272.5{ }^{\circ} \mathrm{C}$ (precipitation in $\left.\mathrm{H}_{2} \mathrm{O}\right)$. IR $\mathrm{v}_{\max }\left(\mathrm{cm}^{-1}\right)$ : $3136(=\mathrm{C}-\mathrm{H})(\mathrm{w}), 1665(\mathrm{C}=\mathrm{O})(\mathrm{s}), 1634$ $(\mathrm{C}=\mathrm{N})(\mathrm{w}), 1330(\mathrm{C}-\mathrm{N})(\mathrm{s}) .{ }^{1} \mathrm{H}$ NMR $\left(600 \mathrm{MHz}, \mathrm{DMSO}-d_{6}, 80^{\circ} \mathrm{C}\right) \delta(\mathrm{ppm}): 8.17$ (dd, J 7.9, $\left.1.1 \mathrm{~Hz}, 1 \mathrm{H}, \mathrm{H}-5\right), 8.12(\mathrm{~s}$, 1H, H-5"), 7.89 (d, J $\left.15.3 \mathrm{~Hz}, 1 \mathrm{H}, \mathrm{H}-2^{\prime}\right), 7.83$ (td, J 8.3, $1.1 \mathrm{~Hz}, 1 \mathrm{H}, \mathrm{H}-7$ ), 7.71 (d, J $8.3 \mathrm{~Hz}, 1 \mathrm{H}, \mathrm{H}-8$ ), 7.69 (d, J 7.5 $\left.\mathrm{Hz}, 2 \mathrm{H}, \mathrm{H}-3^{\prime}\right), 7.58$ (d, J $\left.15.3 \mathrm{~Hz}, 1 \mathrm{H}, \mathrm{H}-1^{\prime}\right), 7.51$ (t, J $\left.7.9 \mathrm{~Hz}, 1 \mathrm{H}, \mathrm{H}-6\right), 7.47-7.41$ (m, 5H, H-4', H-5', H-9'), 7.19 (d, J $\left.8.3 \mathrm{~Hz}, 2 \mathrm{H}, \mathrm{H}-8^{\prime \prime}\right), 5.59$ (s, 2H, H-7"), 5.53 (s, 2H, H-6"). ${ }^{13} \mathrm{C}$ NMR (151 MHz, DMSO-d, $\left.80{ }^{\circ} \mathrm{C}\right) \delta(\mathrm{ppm}): 160.7$ (C-4), 151.6 (C-2), 146.8 (C-8a), 142.8 (C-2'), 139.5 (C-2a'), 139.5 (C-7a'), 135.0 (C-7), 134.8 (C-4'), 134.0 (C-5'), 131.1 (C-9"), 129.5 (C-8"), 129.2 (C-6), 128.4 (C-4'), 127.4 (C-3'), 126.7 (C-8), 125.9 (C-5), 123.3 (C-5"), 120.9 (C4a), 119.9 (C-10"), 119.6 (C-1'), 51.8 (C-7"), 37.9 (C-6"). HRMS-APCl m/z $[\mathrm{M}+\mathrm{H}]^{+}$calcd for $\mathrm{C}_{26} \mathrm{H}_{20} \mathrm{BrN}_{5} \mathrm{O}^{+}$ 498.0929, found 498.0889. Purity (HPLC): $100 \%$.

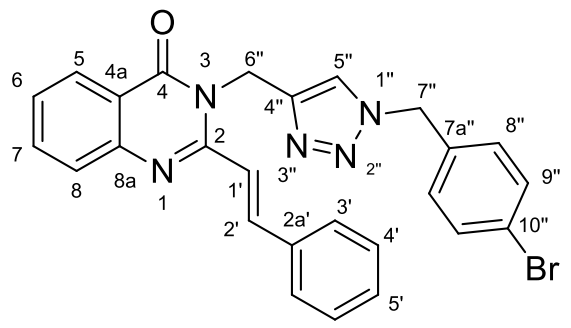

(E)-3-\{[1-(4-Fluorobenzyl)-1H-1,2,3-triazol-4-yl]methyl\}-2-styrylquinazolin-4(3H)-one (4c). The reaction of $2 \mathrm{a}$ $(0.20 \mathrm{~g}, 0.7 \mathrm{mmol})$ with $3 \mathrm{c}(0.12 \mathrm{~g}, 0.77 \mathrm{mmol})$ afforded $4 \mathrm{c}$ as a light-yellow powder $(0.20 \mathrm{~g}, 0.46 \mathrm{mmol}, 65 \%)$. m.p. $236.5-238.6{ }^{\circ} \mathrm{C}$ (precipitation in $\left.\mathrm{H}_{2} \mathrm{O}\right)$. IR $v_{\text {max }}$ : $\left(\mathrm{cm}^{-1}\right)$ : $3135(=\mathrm{C}-\mathrm{H})(\mathrm{w}), 1657(\mathrm{C}=\mathrm{O})(\mathrm{s}), 1632(\mathrm{C}=\mathrm{N})(\mathrm{w})$, 1344 (C-N) (s). ${ }^{1} \mathrm{H}$ NMR (600 MHz, DMSO-d $) \delta(p p m): 8.20\left(\mathrm{~s}, 1 \mathrm{H}, \mathrm{H}-5^{\prime \prime}\right), 8.15$ (d, J $\left.7.8 \mathrm{~Hz}, 1 \mathrm{H}, \mathrm{H}-5\right), 7.89$ (d, J $\left.15.3 \mathrm{~Hz}, 1 \mathrm{H}, \mathrm{H}-2^{\prime}\right), 7.83(\mathrm{t}, J 8.4 \mathrm{~Hz}, 1 \mathrm{H}, \mathrm{H}-7), 7.72$ (d, J $7.3 \mathrm{~Hz}, 2 \mathrm{H}, \mathrm{H}-3$ '), $7.71(\mathrm{~d}, J 8.4 \mathrm{~Hz}, 1 \mathrm{H}, \mathrm{H}-8), 7.63$ (d, J $\left.15.3 \mathrm{~Hz}, 1 \mathrm{H}, \mathrm{H}-1^{\prime}\right), 7.51(\mathrm{t}, J 7.8 \mathrm{~Hz}, 1 \mathrm{H}, \mathrm{H}-6), 7.45$ (t, J $\left.7.2 \mathrm{~Hz}, 2 \mathrm{H}, \mathrm{H}-4^{\prime}\right), 7.42\left(\mathrm{t}, J 7.2 \mathrm{~Hz}, 1 \mathrm{H}, \mathrm{H}-5^{\prime}\right), 7.30$ (dd, J 
8.4, $\left.5.6 \mathrm{~Hz}, 2 \mathrm{H}, \mathrm{H}-8^{\prime \prime}\right), 7.07$ (t, J $\left.8.8 \mathrm{~Hz}, 2 \mathrm{H}, \mathrm{H}-9^{\prime \prime}\right), 5.59$ (s, 2H, H-7"), 5.53 (s, 2H, H-6"). ${ }^{13} \mathrm{C} \mathrm{NMR}(151 \mathrm{MHz}$, DMSO-d $\left.d_{6}\right) \delta(\mathrm{ppm}): 162.5$ (C-4), $161.0\left(\mathrm{C}-10^{\prime \prime}\right), 160.9$ (C-10”), 151.9 (C-2), 147.1 (C-8a), 143.1 (C-2'), 139.88 (C2a'), 135.2 (C-7), 134.6 (C-4"), 132.1 (C-7a'), 132.1 (C-7a”), 130.1 (C-8'), 129.7 (C-5'), 128.9 (C-4'), 127.9 (C-3'), 127.0 (C-6), 126.5 (C-8), 126.4 (C-5), 123.7 (C-5”), 120.0 (C-4a), 119.9 (C-1'), 115.5 (C-9'), 115.3 (C-9'), 51.9 (C$\left.7^{\prime \prime}\right)$, 38.1 (C-6"). HRMS-APCl $m / z[\mathrm{M}+\mathrm{H}]^{+}$calcd for $\mathrm{C}_{26} \mathrm{H}_{21} \mathrm{FN}_{5} \mathrm{O}^{+} 438.1730$, found 438.1712. Purity (HPLC): $100 \%$.

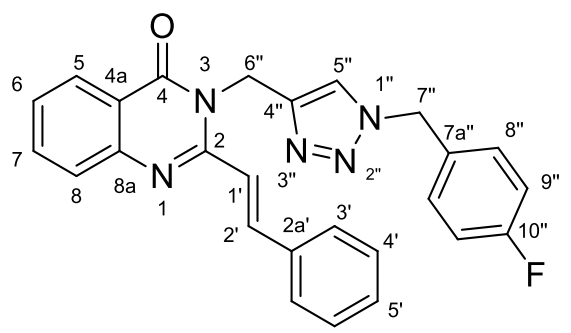

(E)-3-\{[1-Benzyl-1H-1,2,3-triazol-4-yl]methyl\}-2-styrylquinazolin-4(3H)-one (4d). The reaction of $2 \mathrm{a}(0.20 \mathrm{~g}$, $0.7 \mathrm{mmol})$ with $3 \mathrm{~d}(0.10 \mathrm{~g}, 0.77 \mathrm{mmol})$ provided $4 \mathrm{~d}$ as a light grey powder $(0.26 \mathrm{~g}, 0.62 \mathrm{mmol}, 89 \%)$. m.p. 259.2-260.8 ${ }^{\circ} \mathrm{C}$. IR $v_{\text {max }}:\left(\mathrm{cm}^{-1}\right): 3135$ (=C-H) (w), 1666 (C=O) (s), 1635 (C=N) (w), 1332 (C-N) (s). ${ }^{1} \mathrm{H}$ NMR (600 $\left.\mathrm{MHz}, \mathrm{DMSO}-d_{6}, 80^{\circ} \mathrm{C}\right) \delta(\mathrm{ppm}): 8.16(\mathrm{dd}, J 7.9,1.2 \mathrm{~Hz}, 1 \mathrm{H}, \mathrm{H}-5), 8.09\left(\mathrm{~s}, 1 \mathrm{H}, \mathrm{H}-5^{\prime \prime}\right), 7.89$ (d, J $\left.15.3 \mathrm{~Hz}, 1 \mathrm{H}, \mathrm{H}-2^{\prime}\right)$, 7.82 (td, J 7.6, 1.2 Hz, 1H, H-7), 7.70 (dd, J 7.6, 4.0 Hz, 3H, H-8, H-3'), 7.59 (d, J $\left.15.3 \mathrm{~Hz}, 1 \mathrm{H}, \mathrm{H}-1^{\prime}\right), 7.50$ (t, J 7.9 $\mathrm{Hz}, 1 \mathrm{H}, \mathrm{H}-6), 7.45$ (t, J $\left.7.2 \mathrm{~Hz}, 2 \mathrm{H}, \mathrm{H}-4^{\prime}\right), 7.41$ (t, J $\left.7.2 \mathrm{~Hz}, 1 \mathrm{H}, \mathrm{H}-5^{\prime}\right), 7.29-7.26$ (m, 3H, H-9', H-10"), 7.23 (dd, J 6.6, $\left.2.9 \mathrm{~Hz}, 2 \mathrm{H}, \mathrm{H}-8^{\prime \prime}\right), 5.58\left(\mathrm{~s}, 2 \mathrm{H}, \mathrm{H}-7^{\prime \prime}\right), 5.54\left(\mathrm{~s}, 2 \mathrm{H}, \mathrm{H}-6^{\prime \prime}\right) .{ }^{13} \mathrm{C}$ NMR $\left(151 \mathrm{MHz}, \mathrm{DMSO}-d_{6}, 80^{\circ} \mathrm{C}\right) \delta(\mathrm{ppm}): 160.7$ (C-4), 151.6 (C-2), 146.8 (C-8a), 142.7 (C-2'), 139.5 (C-2a'), 135.4 (C-7a”), 135.0 (C-7), 134.0 (C-4”), 129.2 (C-5'), 128.4 (C-4'), 128.1 (C-9'), 127.6 (C-6), 127.4 (C-3'), 127.3 (C-8'), 126.7 (C-10", C-F), 125.9 (C-8), 125.9 (C-5), 123.2 (C-5"), 119.9 (C-4a), 119.6 (C-1'), 52.5 (C-7"), 38.0 (C-6"). HRMS-APCl m/z [M+H] calcd for $\mathrm{C}_{26} \mathrm{H}_{22} \mathrm{~N}_{5} \mathrm{O}^{+}$ 420.1824, found 420.1796. Purity (HPLC): $100 \%$.

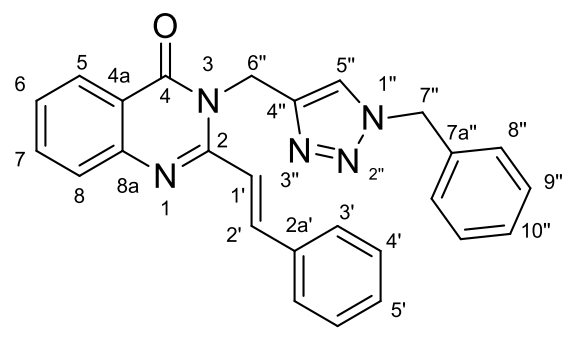

(E)-3-\{[1-(4-Methylbenzyl)-1H-1,2,3-triazol-4-yl]methyl\}-2-styrylquinazolin-4(3H)-one (4e). The reaction of 2a $(0.20 \mathrm{~g}, 0.7 \mathrm{mmol})$ with $3 \mathrm{e}(0.11 \mathrm{~g}, 0.77 \mathrm{mmol})$ afforded $4 \mathrm{e}$ as a light yellow powder $(0.20 \mathrm{~g}, 0.47 \mathrm{mmol}, 67 \%)$. m.p. $238.5-240.7{ }^{\circ} \mathrm{C}$ (precipitation in $\left.\mathrm{H}_{2} \mathrm{O}\right)$. IR $\mathrm{v}_{\text {max }}$ : $\left(\mathrm{cm}^{-1}\right)$ : $3133(=\mathrm{C}-\mathrm{H})(\mathrm{w}), 1664(\mathrm{C}=\mathrm{O})(\mathrm{s}), 1633(\mathrm{C}=\mathrm{N})(\mathrm{w})$, 1346 (C-N) (s). ${ }^{1} \mathrm{H}$ NMR (600 MHz, DMSO-d $\left.{ }_{6}, 80^{\circ} \mathrm{C}\right) \delta(\mathrm{ppm}): 8.16$ (dd, J 7.9, $\left.1.1 \mathrm{~Hz}, 1 \mathrm{H}, \mathrm{H}-5\right), 8.05\left(\mathrm{~s}, 1 \mathrm{H}, \mathrm{H}-5^{\prime \prime}\right)$, 7.89 (d, J $\left.15.3 \mathrm{~Hz}, 1 \mathrm{H}, \mathrm{H}-2^{\prime}\right), 7.82(\mathrm{td}, J 8.4,1.1 \mathrm{~Hz}, 1 \mathrm{H}, \mathrm{H}-7), 7.70$ (d, J $7.82 \mathrm{~Hz}, 1 \mathrm{H}, \mathrm{H}-8$ ), 7.69 (d, J $6.7 \mathrm{~Hz}, 2 \mathrm{H}, \mathrm{H}-$ 3'), 7.58 (d, J $\left.15.3 \mathrm{~Hz}, 1 \mathrm{H}, \mathrm{H}-1^{\prime}\right), 7.50(\mathrm{t}, J 7.9 \mathrm{~Hz}, 1 \mathrm{H}, \mathrm{H}-6), 7.45\left(\mathrm{t}, J 7.2 \mathrm{~Hz}, 2 \mathrm{H}, \mathrm{H}-4^{\prime}\right), 7.41\left(\mathrm{t}, J 7.2 \mathrm{~Hz}, 1 \mathrm{H}, \mathrm{H}_{-} 5^{\prime}\right)$, 7.13 (d, J $\left.8.0 \mathrm{~Hz}, 2 \mathrm{H}, \mathrm{H}-8^{\prime \prime}\right), 7.07$ (d, J $\left.7.9 \mathrm{~Hz}, 2 \mathrm{H}, \mathrm{H}-9^{\prime \prime}\right), 5.57$ (s, 2H, H-7"), 5.48 (s, 2H, H-6"), 2.25 (s, 3H, H-11"). ${ }^{13} \mathrm{C} \mathrm{NMR}\left(151 \mathrm{MHz}\right.$, DMSO- $\left.d_{6}, 80{ }^{\circ} \mathrm{C}\right) \delta(\mathrm{ppm}): 160.7$ (C-4), 151.6 (C-2), 146.8 (C-8a), 142.7 (C-2'), 139.5 (C-10'), 137.0 (C-2a'), 135.0 (C-7), 134.0 (C-7a'), 132.3 (C-4"), 129.1 (C-5'), 128.7 (C-9'), 128.4 (C-4'), 127.4 (C-3'), 127.4 (C-8'), 126.6 (C-6), 125.9 (C-8), 124.9 (C-5), 123.1 (C-5'), 119.9 (C-4a), 119.6 (C-1'), 52.4 (C-7'), 38.0 (C$\left.6^{\prime \prime}\right), 20.1$ (C-11"). HRMS-APCI $m / z[\mathrm{M}+\mathrm{H}]^{+}$calcd for $\mathrm{C}_{27} \mathrm{H}_{24} \mathrm{~N}_{5} \mathrm{O}^{+} 434.1981$, found 434.1942. Purity (HPLC): $100 \%$. 


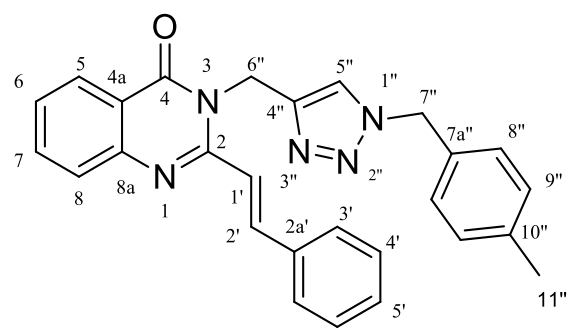

(E)-2-(4-Methoxy-styryl)-3-\{[1-(4-nitrobenzyl)-1H-1,2,3-triazol-4-yl]-methyl\}-quinazolin-4(3H)-one (4f). The reaction of $\mathbf{2 b}(0.22 \mathrm{~g}, 0.7 \mathrm{mmol})$ with $\mathbf{3 a}(0.12 \mathrm{~g}, 0,77 \mathrm{mmol})$ afforded $\mathbf{4 f}$ as a pale orange powder $(0.19 \mathrm{~g}, 0.38$ mmol, 54\%). m.p. $343.5-343.6^{\circ} \mathrm{C}$ (precipitation in $\left.\mathrm{H}_{2} \mathrm{O}\right)$. IR $\mathrm{v}_{\max }$ : $\left(\mathrm{cm}^{-1}\right): 3125$ (=C-H) (w), $1666(\mathrm{C}=\mathrm{O})(\mathrm{s}), 1635$ $(\mathrm{C}=\mathrm{N})(\mathrm{w}), 1519\left(\mathrm{NO}_{2}\right)(\mathrm{s}), 1347(\mathrm{C}-\mathrm{N})(\mathrm{s}), 1252\left(\mathrm{O}-\mathrm{CH}_{3}\right)(\mathrm{s}) .{ }^{1} \mathrm{H}$ NMR $\left(600 \mathrm{MHz}, \mathrm{DMSO}-d_{6}, 80{ }^{\circ} \mathrm{C}\right) \delta(\mathrm{ppm}): 8.17(\mathrm{~s}$, $\left.1 \mathrm{H}, \mathrm{H}-5^{\prime \prime}\right), 8.15(\mathrm{~d}, J 7.9 \mathrm{~Hz}, 1 \mathrm{H}, \mathrm{H}-5), 8.07$ (d, J $\left.8.6 \mathrm{~Hz}, 2 \mathrm{H}, \mathrm{H}-9^{\prime \prime}\right), 7.85\left(\mathrm{~d}, J 15.2 \mathrm{~Hz}, 1 \mathrm{H}, \mathrm{H}-2^{\prime}\right), 7.81(\mathrm{t}, J 8.1 \mathrm{~Hz}$, $1 \mathrm{H}, \mathrm{H}-7), 7.67(\mathrm{~d}, J 8.1 \mathrm{~Hz}, 1 \mathrm{H}, \mathrm{H}-8), 7.63\left(\mathrm{~d}, J 8.6 \mathrm{~Hz}, 2 \mathrm{H}, \mathrm{H}-3^{\prime}\right), 7.48(\mathrm{t}, J 7.9 \mathrm{~Hz}, 1 \mathrm{H}, \mathrm{H}-6), 7.44(\mathrm{~d}, J 8.6 \mathrm{~Hz}, 2 \mathrm{H}$, $\left.\mathrm{H}-8^{\prime \prime}\right), 7.40\left(\mathrm{~d}, J 15.3 \mathrm{~Hz}, 1 \mathrm{H}, \mathrm{H}-1^{\prime}\right), 6.99\left(\mathrm{~d}, J 8.6 \mathrm{~Hz}, 2 \mathrm{H}, \mathrm{H}-4^{\prime}\right), 5.71\left(\mathrm{~s}, 2 \mathrm{H}, \mathrm{H}-7^{\prime \prime}\right), 5.60\left(\mathrm{~s}, 2 \mathrm{H}, \mathrm{H}-6^{\prime \prime}\right), 3.83(\mathrm{~s}, 3 \mathrm{H}$, $\left.\mathrm{H}-6^{\prime}\right) .{ }^{13} \mathrm{C}$ NMR $\left(151 \mathrm{MHz}, \mathrm{DMSO}-d_{6}, 80^{\circ} \mathrm{C}\right) \delta(\mathrm{ppm}): 160.8$ (C-4), 160.4 (C-5'), 151.9 (C-2), 147.0 (C-8a), 146.9 $\left(C-10^{\prime \prime}\right), 143.0\left(C^{\prime}-7 a^{\prime \prime}\right), 142.7$ (C-2'), 139.3 (C-7), 134.0 (C-4"), 129.0 (C-3'), 128.4 (C-8'), 127.6 (C-2a'), 126.5 (C6), 125.9 (C-8), 125.7 (C-5), 123.6 (C-5'), 123.2 (C-9'”), 119.5 (C-4a), 117.2 (C-1'), 114.1 (C-4'), 54.9 (C-7'), 51.6 $\left(\mathrm{C}-6^{\prime}\right), 37.8$ (C-6"). HRMS-APCl m/z [M+H] ${ }^{+}$calcd for $\mathrm{C}_{27} \mathrm{H}_{23} \mathrm{~N}_{6} \mathrm{O}_{4}{ }^{+} 495.1771$, found 495.1768. Purity (HPLC): $100 \%$.

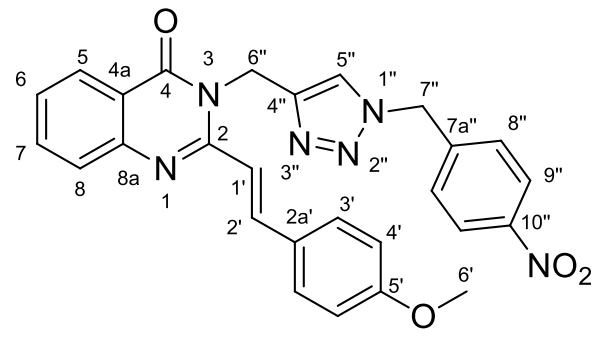

(E)-3-\{[1-(4-Bromobenzyl)-1H-1,2,3-triazol-4-yl]methyl\}-2-(4-methoxy styryl)-quinazolin-4(3H)-one (4g). The reaction of $\mathbf{2 b}(0.22 \mathrm{~g}, 0.7 \mathrm{mmol})$ with $\mathbf{3 b}(0.16 \mathrm{~g}, 0.77 \mathrm{mmol})$ afforded $\mathbf{4 g}$ as a light green powder $(0.30 \mathrm{~g}$, $0.57 \mathrm{mmol}, 82 \%)$. m.p. $246.4-250.7^{\circ} \mathrm{C}$ (precipitation in $\left.\mathrm{H}_{2} \mathrm{O}\right)$. IR $\mathrm{v}_{\max }$ : $\left(\mathrm{cm}^{-1}\right): 3140(=\mathrm{C}-\mathrm{H})(\mathrm{w}), 1661(\mathrm{C}=\mathrm{O})(\mathrm{s})$,

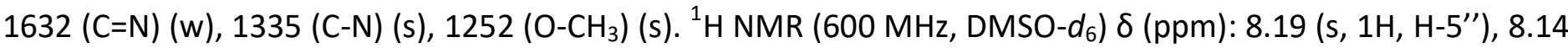
(d, J $7.5 \mathrm{~Hz}, 1 \mathrm{H}, \mathrm{H}-5), 7.87$ (d, J $15.2 \mathrm{~Hz}, 1 \mathrm{H}, \mathrm{H}-2^{\prime}$ ), 7.82 (t, J $7.6 \mathrm{~Hz}, 1 \mathrm{H}, \mathrm{H}-7$ ), 7.68 (d, J $\left.8.4 \mathrm{~Hz}, 3 \mathrm{H}, \mathrm{H}-8, \mathrm{H}-3^{\prime}\right)$, 7.49 (t, J $7.5 \mathrm{~Hz}, 1 \mathrm{H}, \mathrm{H}-6), 7.46-7.41\left(\mathrm{~m}, 3 \mathrm{H}, \mathrm{H}-1^{\prime}, \mathrm{H}-9^{\prime \prime}\right), 7.15$ (d, J $\left.8.1 \mathrm{~Hz}, 2 \mathrm{H}, \mathrm{H}-8^{\prime \prime}\right), 7.01$ (d, J $8.5 \mathrm{~Hz}, 2 \mathrm{H}, \mathrm{H}-$ $\left.4^{\prime}\right), 5.59\left(\mathrm{~s}, 2 \mathrm{H}, \mathrm{H}-7^{\prime \prime}\right), 5.53\left(\mathrm{~s}, 2 \mathrm{H}, \mathrm{H}-6^{\prime \prime}\right), 3.82\left(\mathrm{~s}, 3 \mathrm{H}, \mathrm{H}-6^{\prime}\right) .{ }^{13} \mathrm{C}$ NMR (151 MHz, DMSO-d 6 ) $\delta$ (ppm): 160.77 (C4), 160.4 (C-5'), 151.9 (C-2), 146.9 (C-8a), 142.8 (C-2'), 139.3 (C-7a'), 134.8 (C-7), 133.9 (C-4"), 131.1 (C-9'), 129.5 (C-8'), 129.0 (C-3'), 127.7 (C-2a'), 126.5 (C-6), 125.9 (C-8), 125.6 (C-5), 123.3 (C-5'), 120.8 (C-4a), 119.5 $\left(\mathrm{C}-10^{\prime \prime}\right), 117.2\left(\mathrm{C}-1^{\prime}\right), 114.1$ (C-4'), 55.0 (C-7'), 51.8 (C-6'), 37.9 (C-6"). HRMS-APCl m/z [M+H] calcd for $\mathrm{C}_{27} \mathrm{H}_{23} \mathrm{BrN}_{5} \mathrm{O}_{2}^{+}$528.1035, found 528.1022. Purity (HPLC): $100 \%$. 


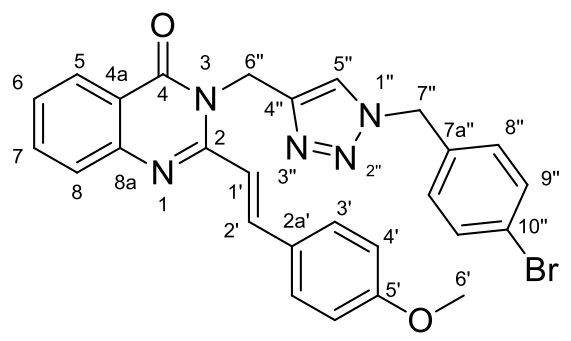

(E)-3-\{[1-(4-Fluorobenzyl)-1H-1,2,3-triazol-4-yl]methyl\}-2-(4-methoxystyryl)-quinazolin-4(3H)-one (4h). The reaction of $2 \mathrm{~b}(0.22 \mathrm{~g}, 0.7 \mathrm{mmol})$ with $3 \mathrm{c}(0.12 \mathrm{~g}, 0.77 \mathrm{mmol})$ resulted in $\mathbf{4 h}$ as a light green powder $(0.25 \mathrm{~g}$, $0.53 \mathrm{mmol}, 75 \%)$. m.p. $229.3-230.7^{\circ} \mathrm{C}$ (precipitation in $\left.\mathrm{H}_{2} \mathrm{O}\right)$. IR $\mathrm{v}_{\max }$ : $\left(\mathrm{cm}^{-1}\right): 3111(=\mathrm{C}-\mathrm{H})(\mathrm{w}), 1657(\mathrm{C}=\mathrm{O})(\mathrm{s})$, 1343 (C-N) (s), $1249\left(\mathrm{O}-\mathrm{CH}_{3}\right)(\mathrm{s}) .{ }^{1} \mathrm{H}$ NMR (600 MHz, DMSO-d 6 ) $\delta(\mathrm{ppm}): 8.18\left(\mathrm{~s}, 1 \mathrm{H}, \mathrm{H}-5^{\prime \prime}\right), 8.13(\mathrm{~d}, J 7.8 \mathrm{~Hz}, 1 \mathrm{H}$, $\mathrm{H}-5$ ), 7.87 (d, J $\left.15.2 \mathrm{~Hz}, 1 \mathrm{H}, \mathrm{H}-2^{\prime}\right), 7.82(\mathrm{t}, J 8.4 \mathrm{~Hz}, 1 \mathrm{H}, \mathrm{H}-7), 7.68$ (d, J $\left.8.4 \mathrm{~Hz}, 3 \mathrm{H}, \mathrm{H}-8, \mathrm{H}-3^{\prime}\right), 7.48(\mathrm{t}, J 7.8 \mathrm{~Hz}, 1 \mathrm{H}$, $\mathrm{H}-6), 7.46$ (d, J $\left.15.2 \mathrm{~Hz}, 1 \mathrm{H}, \mathrm{H}-1^{\prime}\right), 7.30$ (dd, J 8.3, $\left.5.6 \mathrm{~Hz}, 2 \mathrm{H}, \mathrm{H}-8^{\prime \prime}\right), 7.08$ (t, J $8.8 \mathrm{~Hz}, 2 \mathrm{H}, \mathrm{H}-9^{\prime \prime}$ ), 7.01 (d, J $8.6 \mathrm{~Hz}$, $\left.2 \mathrm{H}, \mathrm{H}-4^{\prime}\right), 5.57\left(\mathrm{~s}, 2 \mathrm{H}, \mathrm{H}-7^{\prime \prime}\right), 5.53\left(\mathrm{~s}, 2 \mathrm{H}, \mathrm{H}-6^{\prime \prime}\right), 3.82\left(\mathrm{~s}, 3 \mathrm{H}, \mathrm{H}-6^{\prime}\right) .{ }^{13} \mathrm{C} \mathrm{NMR}\left(151 \mathrm{MHz}, \mathrm{DMSO}-d_{6}\right) \delta(\mathrm{ppm}): 162.3$

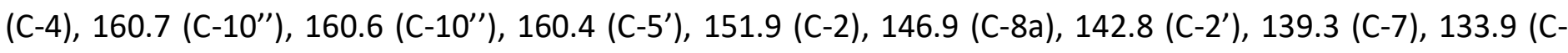
$\left.4^{\prime \prime}\right), 131.6\left(C-7 a^{\prime \prime}\right), 131.5\left(C-7 a^{\prime \prime}\right), 129.6\left(C-8^{\prime \prime}\right), 129.6$ (C-8"), 129.0 (C-3'), 127.7 (C-2a'), 126.5 (C-6), 125.9 (C-8), 125.6 (C-5), 123.1 (C-5") 119.5 (C-4a), 117.2 (C-1'), 115.0 (C-9'), 114.8 (C-9"), 114.1 (C-4'), 54.9 (C-7'), 51.7 $\left(\mathrm{C}-6^{\prime}\right), 37.9\left(\mathrm{C}-6^{\prime \prime}\right)$. HRMS-APCl $\mathrm{m} / \mathrm{z}[\mathrm{M}+\mathrm{H}]^{+}$calcd for $\mathrm{C}_{27} \mathrm{H}_{23} \mathrm{FN}_{5} \mathrm{O}_{2}{ }^{+} 468.1836$, found 468.1819. Purity (HPLC): $100 \%$.

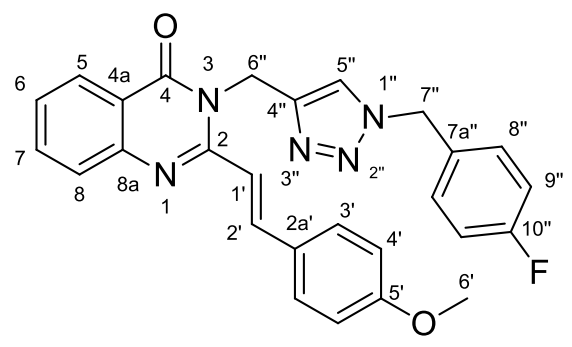

(E)-3-\{[1-Benzyl-1H-1,2,3-triazol-4-yl]methyl\}-2-(4-methoxystyryl)quinazolin-4(3H)-one (4i). The reaction of 2b $(0.22 \mathrm{~g}, 0.7 \mathrm{mmol})$ with $\mathbf{3 d}(0.10 \mathrm{~g}, 0.77 \mathrm{mmol})$ provided $4 \mathbf{i}$ as a yellow powder $(0.12 \mathrm{~g}, 0.26 \mathrm{mmol}, 37 \%)$. m.p. $224.7-226.9^{\circ} \mathrm{C}$ (precipitation in $\left.\mathrm{H}_{2} \mathrm{O}\right)$. IR $\mathrm{v}_{\text {max }}$ : $\left(\mathrm{cm}^{-1}\right)$ : $3107(=\mathrm{C}-\mathrm{H}), 1654(\mathrm{C}=\mathrm{O}), 1346(\mathrm{C}-\mathrm{N}), 1254\left(\mathrm{O}-\mathrm{CH}_{3}\right)$. ${ }^{1} \mathrm{H}$ NMR $\left(600 \mathrm{MHz}, \mathrm{DMSO}-d_{6}, 80{ }^{\circ} \mathrm{C}\right) \delta(\mathrm{ppm}): 8.14(\mathrm{dd}, J$ 7.9, $1.2 \mathrm{~Hz}, 1 \mathrm{H}, \mathrm{H}-5), 8.08\left(\mathrm{~s}, 1 \mathrm{H}, \mathrm{H}-5^{\prime \prime}\right), 7.87$ (d, J 15.3 $\left.\mathrm{Hz}, 1 \mathrm{H}, \mathrm{H}-2^{\prime}\right), 7.80$ (td, J 8.1, $\left.1.2 \mathrm{~Hz}, 1 \mathrm{H}, \mathrm{H}-7\right), 7.67$ (d, J $\left.8.1 \mathrm{~Hz}, 1 \mathrm{H}, \mathrm{H}-8\right), 7.64$ (d, J $\left.8.7 \mathrm{~Hz}, 2 \mathrm{H}, \mathrm{H}-3^{\prime}\right), 7.47$ (t, J 7.9 $\mathrm{Hz}, 1 \mathrm{H}, \mathrm{H}-6), 7.43$ (d, J $\left.15.3 \mathrm{~Hz}, 1 \mathrm{H}, \mathrm{H}-1^{\prime}\right), 7.30-7.28$ (m, 3H, H-9', H-10'”), 7.24 (dd, J 6.7, 2.7 Hz, 2H, H-8'), $7.01\left(\mathrm{~d}, J 8.7 \mathrm{~Hz}, 2 \mathrm{H}, \mathrm{H}-4^{\prime}\right), 5.57\left(\mathrm{~s}, 2 \mathrm{H}, \mathrm{H}-7^{\prime \prime}\right), 5.54\left(\mathrm{~s}, 2 \mathrm{H}, \mathrm{H}-6^{\prime \prime}\right), 3.84\left(\mathrm{~s}, 3 \mathrm{H}, \mathrm{H}-6^{\prime}\right) .{ }^{13} \mathrm{C}$ NMR (151 MHz, DMSO$\left.d_{6}, 80^{\circ} \mathrm{C}\right) \delta(\mathrm{ppm}): 161.0(\mathrm{C}-4), 160.5\left(\mathrm{C}-5^{\prime}\right), 152.1$ (C-2), 147.15 (C-8a), 143.0 (C-2'), 139.6 (C-7a”), 135.7 (C-7), 134.3 (C-4") 129.4 (C-3'), 128.4 (C-9'), 127.8 (C-2a'), 127.8 (C-6), 127.6 (C-8'), 126.8 (C-8), 126.2 (C-5), 126.0 $\left(\mathrm{C}-10^{\prime \prime}\right), 123.6\left(\mathrm{C}-5^{\prime \prime}\right), 119.6$ (C-4a), 117.3 (C-1'), 114.3 (C-4'), 55.2 (C-7'), 52.7 (C-6'), 38.0 (C-6"). HRMS-APCI $m / z[\mathrm{M}+\mathrm{H}]^{+}$calcd for $\mathrm{C}_{27} \mathrm{H}_{24} \mathrm{~N}_{5} \mathrm{O}_{2}^{+} 450.1930$, found 450.1910. Purity (HPLC): $100 \%$. 


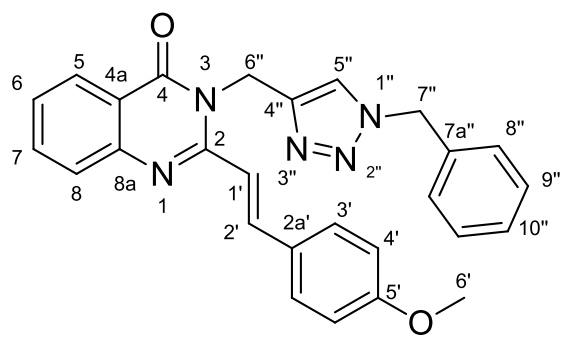

(E)-2-(4-Methoxystyryl)-3-\{[1-(4-methylbenzyl)-1H-1,2,3-triazol-4-yl]-methyl\}-quinazolin-4(3H)-one (4j). The reaction of $2 \mathbf{b}(0.22 \mathrm{~g}, 0.7 \mathrm{mmol})$ with $3 \mathrm{e}(0.11 \mathrm{~g}, 0.77 \mathrm{mmol})$ afforded $4 \mathrm{j}$ as a light-green powder $(0.18 \mathrm{~g}$, 0.39 mmol, 56\%). m.p. $217.5-221.1{ }^{\circ} \mathrm{C}$ (precipitation in $\left.\mathrm{H}_{2} \mathrm{O}\right) . \mathrm{IR} \mathrm{v}_{\max }:\left(\mathrm{cm}^{-1}\right): 3125(=\mathrm{C}-\mathrm{H})(\mathrm{w}), 1668(\mathrm{C}=\mathrm{O})(\mathrm{s})$,

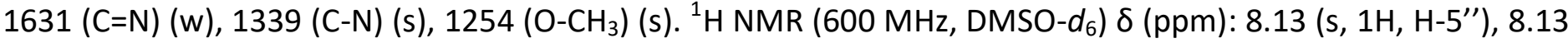
(d, J $7.6 \mathrm{~Hz}, 1 \mathrm{H}, \mathrm{H}-5), 7.87$ (d, J $\left.15.2 \mathrm{~Hz}, 1 \mathrm{H}, \mathrm{H}-2^{\prime}\right), 7.81$ (t, J $8.1 \mathrm{~Hz}, 1 \mathrm{H}, \mathrm{H}-7$ ), 7.67 (d, J $\left.8.1 \mathrm{~Hz}, 3 \mathrm{H}, \mathrm{H}-8, \mathrm{H}-3^{\prime}\right)$, $7.48(\mathrm{t}, J 7.6 \mathrm{~Hz}, 1 \mathrm{H}, \mathrm{H}-6), 7.45\left(\mathrm{~d}, J 15.1 \mathrm{~Hz}, 1 \mathrm{H}, \mathrm{H}-1^{\prime}\right), 7.11\left(\mathrm{~d}, J 7.9 \mathrm{~Hz}, 2 \mathrm{H}, \mathrm{H}-8^{\prime \prime}\right), 7.05\left(\mathrm{~d}, J 7.8 \mathrm{~Hz}, 2 \mathrm{H}, \mathrm{H}-9^{\prime \prime}\right)$, $7.01\left(\mathrm{~d}\right.$, J $\left.8.6 \mathrm{~Hz}, 2 \mathrm{H}, \mathrm{H}-4^{\prime}\right), 5.57$ (s, 2H, H-7'), 5.48 (s, 2H, H-6"), $3.82\left(\mathrm{~s}, 3 \mathrm{H}, \mathrm{H}-6^{\prime}\right), 2.22\left(\mathrm{~s}, 3 \mathrm{H}, \mathrm{H}-11^{\prime \prime}\right) .{ }^{13} \mathrm{C} \mathrm{NMR}$ (151 MHz, DMSO-d 6 ) $\delta$ (ppm): 161.1 (C-4), 160.66 (C-5'), 152.2 (C-2), 147.2 (C-8a), 143.1 (C-2'), 139.7 (C-10”), 137.35 (C-7), 134.5 (C-7a"'), 132.8 (C-4"), 129.6 (C-3'), 129.1 (C-9"), 127.9 (C-2a'), 127.8 (C-8'), 126.9 (C-6), 126.4 (C-8), 126.1 (C-5), 123.6 (C-5'), 119.7 (C-4a), 117.3 (C-1'), 114.4 (C-4'), 55.3 (C-7'), 52.5 (C-6'), 38.1 (C6"), 20.6 (C-11"). HRMS-APCl m/z [M+H] ${ }^{+}$calcd for $\mathrm{C}_{28} \mathrm{H}_{26} \mathrm{~N}_{5} \mathrm{O}_{2}{ }^{+}$464.2088, found 464.2077. Purity (HPLC): $100 \%$.

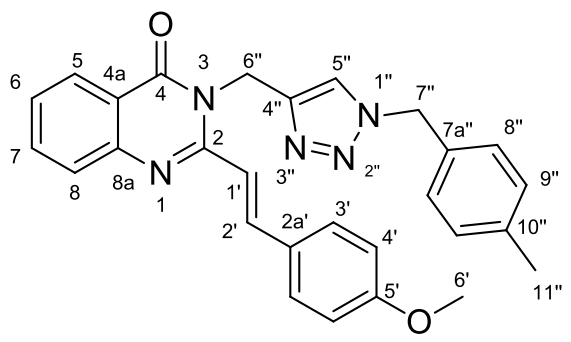

\section{In vitro biological evaluation}

Antileishmanial activity assay. The antipromastigote activities of the synthesized compounds were evaluated, using the resazurin assay method in Horn et al., ${ }^{37}$ against L. donovani (strains $1 \mathrm{~S}$ (MHOM/SD/62/1S) and 9515 (MHOM/IN/95/9515)) and L. major (strain IR-173 (MHOM/IR/-173)). A concentration of $100 \mu \mathrm{M}$ was used for activity screening. An incubation period of $2 \mathrm{~h}$ (1S promastigotes) to $4 \mathrm{~h}$ (9515 and IR-173 promastigotes) was used after the addition of resazurin solution.

Cytotoxicity assay. The cytotoxicities of the synthesized compounds were evaluated in Vero cells (Cellonex, South Africa), using the resazurin assay method in Janse van Rensburg et al. ${ }^{37}$

\section{Acknowledgements}

This work was based upon research financially supported by the National Research Foundation (NRF) (UID 98937 and IFRR 115349) and the North-West University. The authors extend their thanks to Dr. D. Otto for NMR analysis, Dr. J.H.L. Jordaan for NMR and HRMS analysis, Prof F van der Kooy for HPLC analysis.

The following reagents were obtained through BEI Resources, NIAID, NIH: 
Leishmania donovani, Strain 1S (MHOM/SD/62/1S), NR-48821

Leishmania donovani, Strain 9515 (MHOM/IN/95/9515), NR-48822

Leishmania major, Strain IR173 (MHOM/IR/-173), NR-48816

\section{Supplementary Material}

Supplementary data $\left({ }^{1} \mathrm{H},{ }^{13} \mathrm{C}\right.$, IR and HRMS spectra of all quinazolinones), and the HPLC purity determination procedure associated with this article, are available in the online version.

\section{References}

1. Akhoundi, M.; Kuhls, K.; Cannet, A.; Votýpka, J.; Marty, P.; Delaunay, P.; Sereno, D. PLoS Negl Trop Dis. 2016, 10, e0004349.

https://doi.org/10.1371/journal.pntd.0004349

2. Bañuls, A. L.; Hide, M.; Prugnolle, F. Adv Parasitol. 2007, 64, 1-109.

https://doi.org/10.1016/S0065-308X(06)64001-3

3. Lindoso, J. A. L.; Cunha, M. A.; Queiroz, I. T.; Moreira, C. H. V. HIV/AIDS (Auckland, N.Z.). 2016, 8, 147-156. https://doi.org/10.2147/HIV.S93789

4. Castelli, F.; Sulis, G. Clin Microbiol Infect. 2017, 23, 283-289. https://doi.org/10.1016/i.cmi.2017.03.012

5. Feasey, N.; Wansbrough-Jones, M.; Mabey, D. C.; Solomon, A. W. Br Med Bull. 2010, 93, 179-200. https://doi.org/10.1093/bmb/ldp046

6. WHO, Global Health Observatory (GHO) data: Leishmaniasis; https://www.who.int/gho/neglected_diseases/leishmaniasis/en/. [Date of access: 4 June 2020] 2020.

7. WHO, Leishmaniasis: The disease; https://www.who.int/leishmaniasis/disease/en/. [Date of access: 9 Feb. 2020]. 2019a.

8. WHO, Leishmaniasis: Epidemiology; https://www.who.int/leishmaniasis/burden/en/. [Date of access: 9 February 2020]. 2019b.

9. Ponte-Sucre, A.; Gamarro, F.; Dujardin, J.-C.; Barrett, M. P.; López-Vélez, R.; García-Hernández, R.; Pountain, A. W.; Mwenechanya, R.; Papadopoulou, B. PLoS Negl Trop Dis. 2017, 11, e0006052-e0006052. https://doi.org/10.1371/journal.pntd.0006052

10. Pankevich, D. E.; Altevogt, B. M.; Dunlop, J.; Gage, F. H.; Hyman, S. E. Neuron. 2014, 84, 546-553. https://doi.org/10.1016/j.neuron.2014.10.007

11. Viegas-Junior, C.; Danuello, A.; da Silva Bolzani, V.; Barreiro, E. J.; Fraga, C. A. Curr Med Chem. 2007, 14, 1829-1852.

https://doi.org/10.2174/092986707781058805

12. Muregi, F. W.; Ishih, A. Drug Dev Res. 2010, 71, 20-32.

https://doi.org/ 10.1002/ddr.20345

13. Cardona, G. W.; Yepes, A. F.; Herrera, R. A. Curr Med Chem. 2018, 25, 3637-3679.

https://doi.org/10.2174/0929867325666180309111428

14. Kshirsagar, U. A. Org Biomol Chem. 2015, 13, 9336-9352.

https://doi.org/10.1039/C5OB01379H 
15. Xu, Z.; Zhang, Y.; Fu, H.; Zhong, H.; Hong, K.; Zhu, W. Bioorg Med Chem Lett. 2011, 21, 4005-4007. https://doi.org/10.1016/i.bmcl.2011.05.002

16. Hameed, A.; Al-Rashida, M.; Uroos, M.; Ali, S. A.; Arshia; Ishtiaq, M.; Khan, K. M. Expert Opin Ther Pat. 2018, 28, 281-297.

https://doi.org/10.1080/13543776.2018.1432596

17. Birhan, Y. S.; Bekhit, A. A.; Hymete, A. BMC Res Notes. 2015, 8, 589. https://doi.org/10.1186/s13104-015-1578-x

18. Couturier, C.; Lair, C.; Pellet, A.; Upton, A.; Kaneko, T.; Perron, C.; Cogo, E.; Menegotto, J.; Bauer, A.; Scheiper, B.; Lagrange, S.; Bacqué, E. Bioorg Med Chem Lett. 2016, 26, 5290-5299.

https://doi.org/10.1016/j.bmcl.2016.09.043

19. Birhan, Y. S.; Bekhit, A. A.; Hymete, A. Org Med Chem Lett. 2014, 4, 10.

https://doi.org/ 10.1186/s13588-014-0010-1

20. Kaushik, C. P.; Pahwa, A. Med Chem Res. 2018, 27, 458-469.

https://doi.org/10.1007/s00044-017-2072-x

21. Maji, K.; Abbasi, M.; Podder, D.; Datta, R.; Haldar, D. ChemistrySelect 2018, 3, 10220-10225. https://doi.org/10.1002/slct.201800447

22. Tarawneh, A. H.; Al-Momani, L. A. A.; León, F.; Jain, S. K.; Gadetskaya, A. V.; Abu-Orabi, S. T.; Tekwani, B. L.; Cutler, S. J. Med Chem Res. 2018, 27, 1269-1275.

https://doi.org/10.1007/s00044-018-2146-4

23. Huisgen, R. Angew Chem Int Ed Engl. 1963, 2, 565-598.

https://doi.org/10.1002/anie.196305651

24. Rostovtsev, V. V.; Green, L. G.; Fokin, V. V.; Sharpless, K. B. Angew Chem Int Ed Engl. 2002, 41, $2596-2599$. https://doi.org/10.1002/1521-3773(20020715)41:14<2596::AID-ANIE2596>3.0.CO;2-4

25. Kumar, D.; Jadhavar, P. S.; Nautiyal, M.; Sharma, H.; Meena, P. K.; Adane, L.; Pancholia, S.; Chakraborti, A. K. RSC Advances 2015, 5, 30819-30825.

https://doi.org/10.1039/C5RA03888J

26. Usifoh, C. O.; Scriba, G. K. E. Arch Pharm. 2000, 333, 261-266.

https://doi.org/10.1002/1521-4184(20008)333:8<261::AID-ARDP261>3.0.CO;2-O

27. Cilliers, P.; Seldon, R.; Smit, F. J.; Aucamp, J.; Jordaan, A.; Warner, D. F.; N'Da, D. D. Chem Biol Drug Des. 2019, 94, 1518-1536.

https://doi.org/10.1111/cbdd.13534

28. Fleming, I.; Williams, D. In Spectroscopic Methods in Organic Chemistry; Fleming, I.; Williams, D., Eds.; Springer International Publishing: Switzerland AG, 2019; pp 123-276.

29. Lipinski, C. A.; Lombardo, F.; Dominy, B. W.; Feeney, P. J. Adv Drug Deliv Rev. 2001, 46, 3-26. https://doi.org/10.1016/s0169-409x(00)00129-0

30. Delaney, J. S. J Chem Inf Comput Sci. 2004, 44, 1000-1005. https://doi.org/10.1021/ci034243x

31. Ali, J.; Camilleri, P.; Brown, M. B.; Hutt, A. J.; Kirton, S. B. J Chem Inf Model. 2012, 52, 420-428. https://doi.org/10.1021/ci200387c

32. Daina, A.; Michielin, O.; Zoete, V. Sci Rep. 2017, 7, 42717. https://doi.org/10.1038/srep42717

33. Siqueira-Neto, J. L.; Song, O.-R.; Oh, H.; Sohn, J.-H.; Yang, G.; Nam, J.; Jang, J.; Cechetto, J.; Lee, C. B.; Moon, S.; Genovesio, A.; Chatelain, E.; Christophe, T.; Freitas-Junior, L. H. PLoS Negl Trop Dis. 2010, 4, e675-e675. 
https://doi.org/10.1371/journal.pntd.0000675

34. Adewusi, E. A.; Steenkamp, P.; Fouche, G.; Steenkamp, V. Nat Prod Commun. 2013, 8, 1213-1216.

35. Dabiri, M.; Baghbanzadeh, M.; Delbari, A. S. J Comb Chem 2008, 10 , 700-703. https://doi.org/10.1021/cc800067g

36. Horn, C.-M.; Aucamp, J.; Smit, F. J.; Seldon, R.; Jordaan, A.; Warner, D. F.; N'Da, D. D. Med Chem Res. 2020, 29, 1387-1399.

https://doi.org/10.1007/s00044-020-02553-0

37. Janse van Rensburg, H. D.; Legoabe, L. J.; Terre'Blanche, G.; Aucamp, J. Bioorg Chem. 2020, 94, 103459. https://doi.org/10.1016/j.bioorg.2019.103459

This paper is an open access article distributed under the terms of the Creative Commons Attribution (CC BY) license (http://creativecommons.org/licenses/by/4.0/) 